\title{
Evaluation of the accuracy of thermal dissociation CRDS and LIF techniques for atmospheric measurement of reactive nitrogen species
}

\author{
Caroline C. Womack ${ }^{1}$, J. Andrew Neuman ${ }^{1,2}$, Patrick R. Veres ${ }^{1,2}$, Scott J. Eilerman ${ }^{1,2}$, Charles A. Brock ${ }^{1}$, \\ Zachary C. J. Decker ${ }^{3}$, Kyle J. Zarzana ${ }^{1,2}$, William P. Dube ${ }^{1,2}$, Robert J. Wild ${ }^{1,2}$, Paul J. Wooldridge ${ }^{4}$, \\ Ronald C. Cohen ${ }^{4,5}$, and Steven S. Brown ${ }^{1,3}$ \\ ${ }^{1}$ Chemical Sciences Division, Earth Science Research Laboratory, National Oceanic and Atmospheric Administration, \\ Boulder, CO 80305, USA \\ ${ }^{2}$ Cooperative Institute for Research in Environmental Sciences, University of Colorado, Boulder, Boulder, CO 80309, USA \\ ${ }^{3}$ Department of Chemistry and Biochemistry, University of Colorado, Boulder, Boulder, CO 80309, USA \\ ${ }^{4}$ Department of Chemistry, University of California, Berkeley, Berkeley, CA 94720, USA \\ ${ }^{5}$ Department of Earth and Planetary Science, University of California, Berkeley, Berkeley, CA 94720, USA
}

Correspondence to: Steven S. Brown (steven.s.brown@noaa.gov)

Received: 6 December 2016 - Discussion started: 20 December 2016

Revised: 24 March 2017 - Accepted: 19 April 2017 - Published: 31 May 2017

\begin{abstract}
The sum of all reactive nitrogen species $\left(\mathrm{NO}_{y}\right)$ includes $\mathrm{NO}_{x}\left(\mathrm{NO}_{2}+\mathrm{NO}\right)$ and all of its oxidized forms, and the accurate detection of $\mathrm{NO}_{y}$ is critical to understanding atmospheric nitrogen chemistry. Thermal dissociation (TD) inlets, which convert $\mathrm{NO}_{y}$ to $\mathrm{NO}_{2}$ followed by $\mathrm{NO}_{2}$ detection, are frequently used in conjunction with techniques such as laser-induced fluorescence (LIF) and cavity ring-down spectroscopy (CRDS) to measure total $\mathrm{NO}_{y}$ when set at $>600^{\circ} \mathrm{C}$ or speciated $\mathrm{NO}_{y}$ when set at intermediate temperatures. We report the conversion efficiency of known amounts of several representative $\mathrm{NO}_{y}$ species to $\mathrm{NO}_{2}$ in our TD-CRDS instrument, under a variety of experimental conditions. We find that the conversion efficiency of $\mathrm{HNO}_{3}$ is highly sensitive to the flow rate and the residence time through the TD inlet as well as the presence of other species that may be present during ambient sampling, such as ozone $\left(\mathrm{O}_{3}\right)$. Conversion of $\mathrm{HNO}_{3}$ at $400^{\circ} \mathrm{C}$, nominally the set point used to selectively convert organic nitrates, can range from 2 to $6 \%$ and may represent an interference in measurement of organic nitrates under some conditions. The conversion efficiency is strongly dependent on the operating characteristics of individual quartz ovens and should be well calibrated prior to use in field sampling. We demonstrate quantitative conversion of both gas-phase $\mathrm{N}_{2} \mathrm{O}_{5}$ and particulate ammonium nitrate in
\end{abstract}

the TD inlet at $650{ }^{\circ} \mathrm{C}$, which is the temperature normally used for conversion of $\mathrm{HNO}_{3} \cdot \mathrm{N}_{2} \mathrm{O}_{5}$ has two thermal dissociation steps, one at low temperature representing dissociation to $\mathrm{NO}_{2}$ and $\mathrm{NO}_{3}$ and one at high temperature representing dissociation of $\mathrm{NO}_{3}$, which produces exclusively $\mathrm{NO}_{2}$ and not NO. We also find a significant interference from partial conversion $(5-10 \%)$ of $\mathrm{NH}_{3}$ to $\mathrm{NO}$ at $650{ }^{\circ} \mathrm{C}$ in the presence of representative (50 ppbv) levels of $\mathrm{O}_{3}$ in dry zero air. Although this interference appears to be suppressed when sampling ambient air, we nevertheless recommend regular characterization of this interference using standard additions of $\mathrm{NH}_{3}$ to TD instruments that convert reactive nitrogen to $\mathrm{NO}$ or $\mathrm{NO}_{2}$.

\section{Introduction}

The catalytic cycling of nitrogen oxides $\left(\mathrm{NO}_{x}=\mathrm{NO}+\mathrm{NO}_{2}\right)$ plays a key role in the formation of tropospheric ozone $\left(\mathrm{O}_{3}\right)$ from the photooxidation of volatile organic compounds (VOCs). Reactive nitrogen species, such as alkyl and multifunctional nitrates $\left(\mathrm{ANs}, \mathrm{RONO}_{2}\right)$, peroxy nitrates (PNs, $\left.\mathrm{RO}_{2} \mathrm{NO}_{2}\right)$, and nitric acid $\left(\mathrm{HNO}_{3}\right)$ serve as reservoirs and sinks of $\mathrm{NO}_{x}$. The formation of these species results in a 
chain termination that determines the efficiency of the $\mathrm{O}_{3}$ production cycle and can also transport $\mathrm{NO}_{x}$ far from the original emission source. For this reason, total reactive nitrogen $\left(\mathrm{NO}_{y}=\mathrm{NO}+\mathrm{NO}_{2}+\mathrm{RONO}_{2}+\mathrm{RO}_{2} \mathrm{NO}_{2}+\mathrm{HNO}_{3}+\right.$ $\mathrm{HONO}+\mathrm{NO}_{3}+2 \times \mathrm{N}_{2} \mathrm{O}_{5}+$ aerosol nitrates) is an important tracer in monitoring tropospheric $\mathrm{O}_{3}$ production. Its accurate detection is critical in field measurements of ambient air quality, as $\mathrm{O}_{3}$ is a known health risk, and a number of regions across the US are currently in non-attainment or near nonattainment with national ambient air quality $\mathrm{O}_{3}$ standards (EPA, 2016). However, the sources and fates of $\mathrm{NO}_{y}$ species are complex and remain poorly characterized in some regions. Measured total reactive nitrogen has in some cases deviated significantly from the sum of the measured individual components, $\Sigma \mathrm{NO}_{y, i}$ (see Fahey et al., 1986; Bradshaw et al., 1998; Neuman et al., 2012; and others referenced within). This unmeasured $\mathrm{NO}_{y}$, sometimes referred to as "missing $\mathrm{NO}_{y}$ ", indicates the need for a more complete understanding of total and speciated reactive nitrogen and for accurate analytical instrumentation for $\mathrm{NO}_{y}$ measurement (Crosley, 1996; Williams et al., 1998; Day et al., 2003).

Techniques that detect the major individual components of $\mathrm{NO}_{y}$ include detection of $\mathrm{NO}$ and $\mathrm{NO}_{2}$ by chemiluminescence (Ridley and Howlett, 1974; Kley and McFarland, 1980), cavity ring-down spectroscopy (CRDS; Fuchs et al., 2009), or laser-induced fluorescence (LIF; Thornton et al., 2000), as well as detection of $\mathrm{HNO}_{3}$ by chemical ionization mass spectrometry (CIMS; Fehsenfeld et al., 1998; Huey et al., 1998; Neuman et al., 2002; Huey, 2007) or mist chamber sampling (Talbot et al., 1990). Additionally, speciated peroxyacyl nitrates (PANs) have been detected by gaschromatography electron capture detection (Darley et al., 1963; Flocke et al., 2005) and CIMS (Slusher et al., 2004), while $\mathrm{N}_{2} \mathrm{O}_{5}$ and $\mathrm{ClNO}_{2}$ have been detected by CRDS (Dubé et al., 2006; Thaler et al., 2011) and CIMS (Kercher et al., 2009). HONO has been detected by long path differential optical absorption spectroscopy (Perner and Platt, 1979), and $\mathrm{NO}_{3}$ has been detected by CRDS (King et al., 2000). However, fewer methods have been developed for detection of the broad suite of individual alkyl and multifunctional nitrates, which have been suggested to comprise upwards of $20 \%$ of $\mathrm{NO}_{y}$ in the mid-latitude continental boundary layer and may be higher in remote locations (O'Brien et al., 1995; Day et al., 2003; Worton et al., 2008; Beaver et al., 2012; Xiong et al., 2015; Lee et al., 2016). An alternative to detecting individual components of $\mathrm{NO}_{y}$ is the use of a molybdenum oxide or gold catalyst in the presence of $\mathrm{CO}$ to reduce all $\mathrm{NO}_{y}$ species to $\mathrm{NO}$, followed by $\mathrm{NO}$ detection by chemiluminescence (Winer et al., 1974; Fahey et al., 1986), though catalyst-based techniques are known to require frequent cleaning and are potentially sensitive to contamination and to interferences at ambient levels of ammonia, HCN, acetonitrile and $\mathrm{R}-\mathrm{NO}_{2}$ compounds (Crosley, 1996; Kliner et al., 1997; Bradshaw et al., 1998; Williams et al., 1998; Day et al., 2002). An alternative method developed by Day and co- workers (Day et al., 2002) uses a quartz thermal dissociation (TD) inlet to rapidly thermally convert nearly all $\mathrm{NO}_{y}$ species to $\mathrm{NO}_{2}$, which is then detected by laser-induced fluorescence. The $\mathrm{NO}_{y}$ species in the TD inlet undergo the following reaction:

$X \mathrm{NO}_{2}+$ heat $\rightarrow X+\mathrm{NO}_{2}$,

where $X$ is $\mathrm{HO}, \mathrm{RO}$, or $\mathrm{RO}_{2}$. Heated inlets had previously been used to dissociate PNs (Nikitas et al., 1997), but the TD inlet developed by Day et al. (2002) takes advantage of the different $\mathrm{O}-\mathrm{N}$ bond energies of ANs, PNs, and nitric acid to separately and selectively detect these three classes of $\mathrm{NO}_{y}$. A plot of measured $\mathrm{NO}_{2}$ signal as a function of inlet temperature (hereafter referred to as a "thermogram") yields a stepwise dissociation curve with increases in signal near 100, 300 , and $500^{\circ} \mathrm{C}$, corresponding to the dissociation of PNs, ANs, and $\mathrm{HNO}_{3}$ respectively. By setting the TD oven temperature to one of the three plateaus, they were able to measure each class of $\mathrm{NO}_{y}$, by comparison of the $\mathrm{NO}_{2}$ signal in a given channel to the signal measured at the adjacent lower temperature plateau.

In recent years, a suite of other instruments have incorporated this $\mathrm{NO}_{y} \mathrm{TD}$ inlet method into existing techniques that measure $\mathrm{NO}_{2}$ or the radical co-fragment $X$ in Reaction (R1), such as chemical ionization mass spectrometry (TD-CIMS; Slusher et al., 2004; Zheng et al., 2011; Phillips et al., 2013), cavity ring-down spectroscopy (TD-CRDS; Paul et al., 2009; Thieser et al., 2016), and cavity attenuated phase shift spectroscopy (TD-CAPS; Sadanaga et al., 2016). Each instrument has its own advantages and disadvantages. For example, TDLIF detects $\mathrm{NO}_{2}$ at low pressure following thermal dissociation. Secondary recombination reactions of the dissociated radicals would thus be suppressed in the detection region, although the thermal dissociation inlet may be operated at either high or low pressures in these instruments. However, it is subject to interferences from urban levels of $\mathrm{NO}$ and $\mathrm{NO}_{2}$ (Paul et al., 2009; Wooldridge et al., 2010). TD-CIMS can differentiate between the different types of PNs but requires regular calibration of each species, not all of which have native standards readily available. TD-CAPS is subject to interferences from glyoxal and methylglyoxal (Sadanaga et al., 2016). TD-CRDS is an absolute measurement but can be subject to other interferences, as discussed in Sect. 3 .

Recent TD inlet studies (Day et al., 2002; Paul et al., 2009; Thieser et al., 2016) have measured the conversion efficiency for several AN and PN species with known concentrations in a laboratory setting. These studies all note the possibility of secondary reactions that either increase or decrease the $\mathrm{NO}_{2}$ signal. For example, recombination reactions to reform the AN or PN species prior to reaching the detector will result in a negative bias in $\mathrm{NO}_{2}$ (too little $\mathrm{NO}_{2}$ measured). Likewise, ambient levels of $\mathrm{O}_{3}$ in the sampled air may react in the oven with $\mathrm{NO}$ to form $\mathrm{NO}_{2}$, resulting in a positive bias (Pérez et al., 2007), though this reaction rate depends on the TD inlet pressure and flow rate (Wooldridge et al., 2010). 
Day et al. (2002) found that recombination reactions were significant for PNs but caused minimal problems for nitric acid, since the $\mathrm{OH}$ radical is far more likely to be lost to the walls of the oven than to recombine with $\mathrm{NO}_{2}$. More significant is the reaction of dissociated $\mathrm{RO}_{2}$ and $\mathrm{HO}_{2}$ radicals with ambient levels of $\mathrm{NO}$ and $\mathrm{NO}_{2}$. Thieser et al. (2016) parameterized the bias in peroxyacyl nitrate and 2-propyl nitrate detection in their inlet as a function of ambient $\mathrm{NO}$ and $\mathrm{NO}_{2}$ concentrations but noted that these parameterizations may vary for other PNs or ANs. In cases where the concentration of one category of $\mathrm{NO}_{y}$ species far exceeds the others, such as the high $\mathrm{HNO}_{3}$ : ANs ratios in Pusede et al. (2016), speciated measurements can be significantly affected by biases in measurements of the other $\mathrm{NO}_{y}$ compounds.

A four-channel CRDS instrument (hereby referred to as the NOAA TD-CRDS instrument) for detection of nitrogen oxides was recently developed (Wild et al., 2014). In this instrument, one channel is equipped with a TD inlet set at $650{ }^{\circ} \mathrm{C}$ and is used to measure all $\mathrm{NO}_{y}$ species (including $\mathrm{NO}_{2}$, as well as $\mathrm{NO}$ by chemical conversion with an $\mathrm{O}_{3}$ addition to $\mathrm{NO}_{2}$ ). Two other channels simultaneously monitor $\mathrm{NO}_{2}$ and $\mathrm{NO}$, and so a measurement of $\mathrm{NO}_{z}\left(=\mathrm{NO}_{y}-\mathrm{NO}_{x}\right)$ can be derived. Because NO is intentionally detected as $\mathrm{NO}_{2}$ in the $\mathrm{NO}_{y}$ channel, this instrument avoids the majority of the $\mathrm{NO} \leftrightarrow \mathrm{NO}_{2}$ interconversion interferences that affect many other thermal dissociation instruments. Analogous to the studies which measured the conversion efficiencies of ANs and PNs (Day et al., 2002; Paul et al., 2009; Sadanaga et al., 2016; Thieser et al., 2016), we present here an analysis of the conversion efficiencies of several other $\mathrm{NO}_{y}$ species and the interferences that affect the operation of this high temperature inlet. These interferences include the temperature dependence of $\mathrm{HNO}_{3}$ conversion, which is important to understanding both its quantitative conversion at $650^{\circ} \mathrm{C}$ as well as its potential to interfere with measurements of ANs at lower temperatures. We also compare these results to those from the TD-LIF instrument of Day et al. (2002), hereby referred to as the Berkeley TD-LIF instrument. Additionally, we report the temperature dependence of $\mathrm{N}_{2} \mathrm{O}_{5}$ conversion, which is shown to occur in two steps; first, the conversion efficiency of ammonium nitrate aerosol and finally the interference of $\mathrm{NH}_{3}$ through its partial conversion to NO.

\section{Methods}

\subsection{Thermal dissociation cavity ring-down spectroscopy (TD-CRDS)}

Cavity ring-down spectroscopy is a direct absorption technique for measuring the concentration of trace gases (O'Keefe and Deacon, 1988; Fuchs et al., 2009). The fourchannel $405 \mathrm{~nm}$ NOAA TD-CRDS instrument, which has been used by our group in both lab-based studies and atmospheric sampling (Wild et al., 2014, 2016), simultaneously measures ambient $\mathrm{NO}_{2}$ in one channel, while chemically converting $\mathrm{NO}$ and $\mathrm{O}_{3}$ to $\mathrm{NO}_{2}$ in the second and third channels, and thermally converting $\mathrm{NO}_{y}$ to $\mathrm{NO}_{2}$ in a TD oven in the fourth channel. In this study, we have used only the $\mathrm{NO}_{y}$ channel to study the conversion efficiency of several reactive nitrogen species to $\mathrm{NO}_{2}$. Figure 1 shows a schematic of the relevant instrument plumbing and optical cavity. The details of the optical cavity can be found in Wild et al. (2014); only a brief description of the optical system and the details of the TD inlet that deviate from that study will be described here.

Sampled air is pulled into a $50 \mathrm{~cm}$ long high-finesse optical cavity capped by highly reflective end mirrors, with purge flows of $25 \mathrm{sccm}$ (standard cubic centimeters per minute at $273.15 \mathrm{~K}$ and $1 \mathrm{~atm}$ ) added in front of each mirror to maintain mirror cleanliness. The output of a $0.5 \mathrm{~nm}$ bandwidth, continuous wave diode laser centered at approximately $405 \mathrm{~nm}$ and modulated at $2 \mathrm{kHz}$ is passively coupled into one end of the optical cavity. The laser light builds up in the cavity, and when it is modulated off the decaying output light intensity is monitored by a photomultiplier tube on the far side of the cavity. The measured light decay profiles are summed and fit at a $1 \mathrm{~Hz}$ repetition rate to yield the ring-down time $\tau$. The ring-down time is inversely related to the concentration of the absorbing gas, $\mathrm{NO}_{2}$ in this case, which can be derived as

$\left[\mathrm{NO}_{2}\right]=\frac{R_{L}}{c \sigma}\left(\frac{1}{\tau}-\frac{1}{\tau_{0}}\right)$,

where $R_{L}$ is the ratio of $d$, the mirror separation length, and $l$, which is the distance over which the sample is present. The speed of light is represented by $c, \sigma$ is the absorption cross section of $\mathrm{NO}_{2}$, and $\tau_{0}$ is the ring-down time of a reference cavity without any absorbing gases, which is obtained by flushing the cavity with an excess flow of zero air for $30 \mathrm{~s}$ every 10 to $20 \mathrm{~min}$. If purge volumes were not used, the $R_{L}$ term in Eq. (1) would simply be 1, but, since purge volumes are used here, $\sigma / R_{L}$ is characterized regularly by filling the cavity with several different known $\mathrm{NO}_{2}$ concentrations (obtained by reacting the output of an $\mathrm{O}_{3}$ standard source with excess $\mathrm{NO}$ ) and calculating the slope of the measured optical extinction vs. $\left[\mathrm{NO}_{2}\right]$ as described in Washenfelder et al. (2011). This value was measured approximately once per month during laboratory tests with this instrument but was constant to within $\pm 1 \%$, with an average value of $6.25 \times 10^{-19} \mathrm{~cm}^{2}$. More regular calibrations of the $\sigma / R_{L}$ value during recent field studies show similar stability. The $\mathrm{NO}_{2}$ signal can be measured with a lower detection of 18 pptv $(1 \sigma)$ in $1 \mathrm{~s}$ (Wild et al., 2014).

The $\mathrm{NO}_{y}$ TD oven inlet consists of a quartz tube $(0.39 \mathrm{~cm}$ ID and $63 \mathrm{~cm}$ in length, of which $38 \mathrm{~cm}$ is heated) wrapped in nichrome wire and insulated with fiberglass. The flow rate through the inlet and optical cavity is controlled by a mass flow controller on the downstream side of the optical cavity. Because the standard flow rate is held constant during each experiment, the volumetric flow rate, and therefore the TD residence time, varies with oven temperature. For exam- 


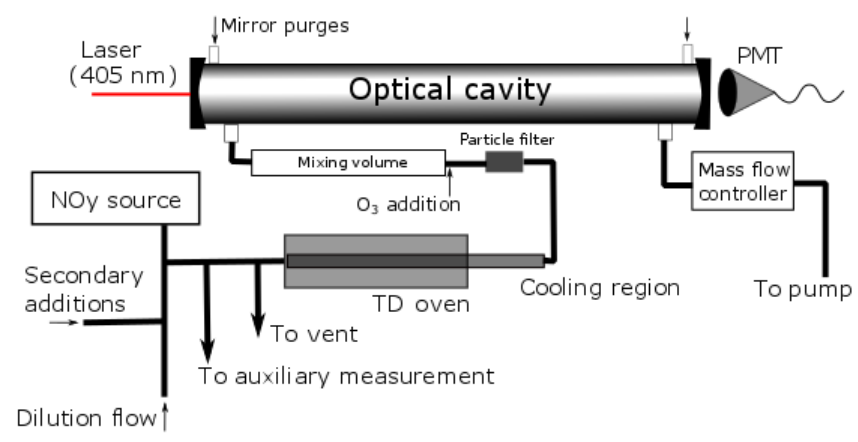

Figure 1. Instrument schematic of the TD-CRDS instrument used in this study. An $\mathrm{NO}_{y}$ source $\left(\mathrm{HNO}_{3}\right.$ permeation tube, $\mathrm{N}_{2} \mathrm{O}_{5}$ cold trap, $\mathrm{NH}_{4} \mathrm{NO}_{3}$ particle atomizer + DMA size selector, or $\mathrm{NH}_{3}$ permeation tube) is diluted by a zero air flow (with an option for adding $\mathrm{O}_{3}$, VOCs, $\mathrm{RH}$, or $\mathrm{CO}$ through the secondary addition port) and passed through the TD oven. A portion of the flow is sampled prior to entering the oven with one of several types of auxiliary measurements (CIMS for $\mathrm{N}_{2} \mathrm{O}_{5}$; an ultra-high sensitivity aerosol spectrometer, UHSAS, for $\mathrm{NH}_{4} \mathrm{NO}_{3}$ particles; or commercial CRDS for $\mathrm{NH}_{3}$ ). After flowing through a cooling region, the sample passes through a particle filter and then is mixed with a $\sim 30$ ppmv addition of $\mathrm{O}_{3}$ in a mixing volume before entering through the optical cavity, where $\mathrm{NO}_{2}$ is measured by CRDS.

ple, the $4.5 \mathrm{~cm}^{3}$ inner volume of the oven results in an oven residence time of 30-100 ms at a flow rate of 1.9 slpm (standard liters per minute; at $273.15 \mathrm{~K}$ and $1 \mathrm{~atm}$ ) for temperatures from 25 to $650{ }^{\circ} \mathrm{C}$. A flow rate of 1.9 slpm represents the normal operating conditions of this instrument, but flow rates between 0.25 and $3 \mathrm{slpm}$ were tested, which provides oven residence times between 20 and $400 \mathrm{~ms}$. The temperature of the TD oven is monitored by a thermocouple mounted to the outer side of the quartz tube and therefore is slightly lower than the temperature of the gas. However, inserting a temperature probe into the inner part of the TD inlet yields a temperature profile, shown in Fig. S1 in the Supplement, which approaches the temperature set point by the end of the inlet. All oven temperatures described hereafter refer to the measured thermocouple temperature. After passing through the TD oven, the gas cools to room temperature in the nonheated portion of the quartz tube, passes through a particle filter ( $47 \mathrm{~mm}$ diameter, $1 \mu \mathrm{m}$ pore size PTFE membrane) to remove non-volatilized particles, and then enters a $15 \mathrm{~cm}^{3}$ mixing volume prior to entering the CRDS cavity. There, $\mathrm{O}_{3}$ ( $\sim 30$ ppmv after dilution) is added to the sampled air to convert any $\mathrm{NO}$ that formed in the thermal dissociation to $\mathrm{NO}_{2}$. As the rate constant for the $\mathrm{NO}+\mathrm{O}_{3} \rightarrow \mathrm{NO}_{2}+\mathrm{O}_{2}$ reaction is more than 3 orders of magnitude faster than the $\mathrm{NO}_{2}+\mathrm{O}_{3} \rightarrow$ $\mathrm{NO}_{3}+\mathrm{O}_{2}$ reaction, conversion of $\mathrm{NO}_{2}$ to $\mathrm{NO}_{3}$ (and subsequently to $\mathrm{N}_{2} \mathrm{O}_{5}$ ) is at most $1-2 \%$ in this mixing volume and is corrected for using a previously described method (Fuchs et al., 2009). To measure the thermograms shown in this paper, the oven temperature was set to a sequence of temperatures spanning 300 to $650^{\circ} \mathrm{C}$ and spaced by $25^{\circ} \mathrm{C}$ in a ran- dom order. The measured $\mathrm{NO}_{2}$ concentrations are averaged at each temperature set point for approximately $10-15 \mathrm{~min}$.

\section{2 $\mathrm{NO}_{y}$ samples and additions}

Samples of reactive nitrogen species (labeled as " $\mathrm{NO}_{y}$ source" in Fig. 1) were introduced into the TD oven in several ways. $\mathrm{HNO}_{3}$ and $\mathrm{NH}_{3}$ were obtained by passing a $50 \mathrm{sccm}$ flow of zero air through a calibrated $45^{\circ} \mathrm{C}$ permeation tube containing $\mathrm{HNO}_{3}$ (VICI Metronics) or $\mathrm{NH}_{3}$ (KinTek), providing gaseous outputs of 64 and $23 \mathrm{ng} \mathrm{min}^{-1}$, respectively (Neuman et al., 2003). Subsequent dilution in 0.5-4 slpm zero (synthetic) air resulted in $\mathrm{HNO}_{3}$ and $\mathrm{NH}_{3}$ concentrations of 5 to $40 \mathrm{ppbv}$. Because both these species readily adsorb to instrument surfaces (Neuman et al., 1999), only fluorinated ethylene propylene (FEP) Teflon tubing was used between the permeation tube and the TD oven, and all tubing was kept as short as possible (typically less than $30 \mathrm{~cm}$ ) and was wrapped in $100^{\circ} \mathrm{C}$ heating tape to reduce losses to the walls. However, these precautions were found to be unnecessary in this laboratory study, since the constant flow from the permeation tube resulted in an equilibrium in which the adsorption losses to the walls were equal to the rate of offgassing.

NO was obtained by dilution of the output of a calibrated standard (Scott-Marrin, $0.2 \%$ in $\mathrm{N}_{2}$ ). $\mathrm{N}_{2} \mathrm{O}_{5}$ was synthesized via a procedure adapted from Davidson et al. (1978) and Bertram et al. (2009), which has been used as a calibration for the $\mathrm{N}_{2} \mathrm{O}_{5}$ channel of a CRDS $\mathrm{NO}_{3}$ instrument (Dubé et al., 2006; Wagner et al., 2011). Pure samples of $\mathrm{NO}$ and $\mathrm{O}_{2}$ were mixed to yield $\mathrm{NO}_{2}$, and this mixture was reacted in a flow tube with excess $\mathrm{O}_{3}$, yielding $\mathrm{NO}_{3}$ which then reacted with $\mathrm{NO}_{2}$ to form $\mathrm{N}_{2} \mathrm{O}_{5}$. The resulting mixture flowed through a glass trap at $-78^{\circ} \mathrm{C}$, where $\mathrm{N}_{2} \mathrm{O}_{5}$ solidified as a white crystal. A gaseous sample of $\mathrm{N}_{2} \mathrm{O}_{5}$ was obtained by flowing $20-50 \mathrm{sccm}$ of zero air over the solid $-78^{\circ} \mathrm{C}$ sample and then diluting further in zero air. Gas-phase $\mathrm{N}_{2} \mathrm{O}_{5}$ prepared in this way is known to contain variable but significant amounts of $\mathrm{HNO}_{3}$ (Bertram et al., 2009), and thus efforts were made to minimize this interference by baking all glassware for several hours before use and by distilling the solid $\mathrm{N}_{2} \mathrm{O}_{5}$ sample regularly by bringing it to room temperature under an $\mathrm{O}_{3}$ flow for $10 \mathrm{~min}$. Nevertheless, some $\mathrm{HNO}_{3}$ was always present in the sample, and therefore the output of the trap was passed through a nylon wool scrubber prior to entering the TD oven, which removed $\mathrm{HNO}_{3}$ without significantly perturbing the $\mathrm{N}_{2} \mathrm{O}_{5}$ concentration. Finally, ammonium nitrate particles were generated by running a $0.1 \mathrm{~g} \mathrm{~L}^{-1}$ solution of aqueous $\mathrm{NH}_{4} \mathrm{NO}_{3}$ through an atomizer and size-selecting particles of a certain diameter with a custom-built differential mobility analyzer (DMA). Conductive tubing, rather than Teflon, was used to minimize electrostatic build-up and loss of particles to the walls before entering the TD oven.

In order to test whether common atmospheric gases would interfere with the conversion efficiency, some additional 
species were added to the sample prior to entering the oven. Water was added by passing the dilution zero air through a water bubbler prior to mixing with the $\mathrm{HNO}_{3}$ sample. Various amounts of $\mathrm{O}_{3}$ were added by running the dilution zero air through an $\mathrm{O}_{3}$ calibrator (Thermo Fisher Scientific 49i) that is also capable of generating up to $200 \mathrm{ppm} \mathrm{O}_{3}$ in $1-3 \mathrm{slpm}$ of zero air. We also investigated the effect of various VOCs, including a high concentration of propane $(\sim 5 \mathrm{ppmv})$ and a standard mixture of VOCs (Air Liquide) consisting of $n$-hexane (1.234 ppm), propanal (0.397 ppm), 2-butanone (1.237), benzene (1.151 ppm), methylcyclohexane $(0.938 \mathrm{ppm})$, ethylbenzene $(1.213 \mathrm{ppm})$, 2,2,4-trimethylpentane $(1.186 \mathrm{ppm})$, isopropyl benzene $(1.148 \mathrm{ppm})$, and ethanol $(0.994 \mathrm{ppm})$. This mixture is commonly used to calibrate gas chromatography-mass spectrometry (GC-MS) instruments but here provides common atmospheric species with a range of masses, bond strengths, and degrees of oxidation. It was diluted to $50 \mathrm{ppbv}$ total VOCs by addition of zero air prior to entering the oven. We also added $\mathrm{CO}$ in varying quantities to the $\mathrm{HNO}_{3}$ and $\mathrm{NH}_{3}$ samples.

\subsection{Ancillary measurements}

Several instruments were used as ancillary confirmation for some of the $\mathrm{NO}_{y}$ sample concentrations. In each case, a Teflon tee split the sample input and a portion of the flow was pulled into the secondary instrument prior to entering the TD oven, as shown in Fig. 1. In the case of $\mathrm{NH}_{3}$, a Picarro $\mathrm{G} 2103 \mathrm{NH}_{3}$ analyzer with a manufacturer's specified $1 \mathrm{ppbv}$ detection limit at $5 \mathrm{~s}$ integration time was used. A custombuilt iodide adduct chemical ionization mass spectrometer (Lee et al., 2014), described in further detail in Veres et al. (2015), was used to monitor the $\mathrm{N}_{2} \mathrm{O}_{5}$ and $\mathrm{HNO}_{3}$ concentrations from the $\mathrm{N}_{2} \mathrm{O}_{5}$ solid sample prior to dissociation in the oven. In this instrument, $\mathrm{N}_{2} \mathrm{O}_{5}$ and $\mathrm{HNO}_{3}$ mixed with $\mathrm{I}^{-}$ ions produced by passing $\mathrm{CH}_{3} \mathrm{I}$ through a ${ }^{210}$ Po source, and the resulting $\mathrm{HNO}_{3} \cdot \mathrm{I}^{-}$and $\mathrm{N}_{2} \mathrm{O}_{5} \cdot \mathrm{I}^{-}$ions were detected by quadrupole mass spectrometry at $m / z=190$ and 235. This measurement has a detection limit of 4 pptv and 70 pptv and error bars of 25 and $25 \%(3 \sigma)$ for $\mathrm{N}_{2} \mathrm{O}_{5}$ and $\mathrm{HNO}_{3}$, respectively. Lastly, an ultra-high sensitivity aerosol spectrometer (Droplet Measurement Technologies) was used to monitor the size distribution of the size-selected ammonium nitrate particles (Cai et al., 2008).

$\mathrm{HNO}_{3}$ and $\mathrm{NH}_{3}$ conversion efficiencies were also tested using ambient air for dilution (rather than synthetic air), as sampled during daytime in August 2016 in Boulder, CO. Ambient air was drawn into the two of the four channels of the NOAA TD-CRDS instrument, through two side-byside identical quartz ovens heated to $650^{\circ} \mathrm{C}$ at a flow rate of $1.4 \mathrm{slpm}$, and the output of either the $\mathrm{NH}_{3}$ or $\mathrm{HNO}_{3}$ permeation tube was inserted directly into the exposed inlet of one of the ovens, for a duration of approximately $6 \mathrm{~min}$. The $\mathrm{NO}_{2}$ signal was measured by one of the remaining channels in the
NOAA TD-CRDS instrument, and the conversion efficiency of each species was calculated by comparing the difference in $\mathrm{NO}_{2}$ signal between the two ovens relative to the calibrated output of the permeation tube to correct for small differences in $\mathrm{NO}_{2}$ signal between the two ovens.

We also present results measured in the Berkeley TD-LIF instrument. It is described in greater detail elsewhere (Day et al., 2002), but briefly $\mathrm{HNO}_{3}$ and $n$-propyl nitrate samples were provided by permeation tubes similar to those described in Sect. 2.2, diluted in dry zero air, and passed through $20 \mathrm{~cm}$ heated length quartz ovens, held at ambient pressure, at a flow rate of $2 \mathrm{slpm}$. This resulted in residence times of approximately $50 \mathrm{~ms}$. The $\mathrm{NO}_{2}$ released in the thermal conversion was supersonically expanded into the detection region and measured by laser-induced fluorescence from an individual rovibronic $\mathrm{NO}_{2}$ line. The $\mathrm{NO}_{y}$ conversion ratio was calculated as the measured $\mathrm{NO}_{2}$ concentration relative to the maximum $\mathrm{NO}_{2}$ signal at high temperatures, as the oven temperature was changed at a rate of $-10^{\circ} \mathrm{C}$ per minute.

\subsection{Box modeling}

A simple kinetic box model was used to support the experimental findings. Reaction rates for $\sim 60$ reactions possibly involved in the dissociation and secondary chemical reactions of each $\mathrm{NO}_{y}$ species (listed in the Supplement) were obtained from the Jet Propulsion Laboratory (JPL) Kinetics Database (Sander et al., 2011) and the NIST Chemical Kinetics Database (Manion et al., 2015) at temperatures spanning the $25-650{ }^{\circ} \mathrm{C}$ range of the experimental thermograms. For every $\mathrm{HNO}_{3}, \mathrm{~N}_{2} \mathrm{O}_{5}$, and $\mathrm{NH}_{3}$ thermogram, a simulation was run at each temperature, assuming a starting concentration of the $\mathrm{NO}_{y}$ species equal to that observed in the experiment and lasting the duration of the residence time in the oven. The simulation was then allowed to keep running at room temperature for an additional $\sim 1 \mathrm{~s}$ to mimic the conditions between the oven and the instrument. During this additional low temperature time, $30 \mathrm{ppmv}$ of $\mathrm{O}_{3}$ was added to the simulation to convert $\mathrm{NO}$ to $\mathrm{NO}_{2}$ as in the TD-CRDS instrument. The final concentration of $\mathrm{NO}_{2}$ at the end of the simulation was recorded for each temperature, which resulted in a simulated thermogram. Several simplifying assumptions were made here. We assume instantaneous heating and cooling of the sample and a uniform temperature profile along the $38 \mathrm{~cm}$ length of the TD oven. We also only consider gas-phase reactions and neglect any surface-mediated reactions. When possible, JPL-recommended values for the rate constants were used, but many of those listed did not span the full temperature range of the thermograms. When JPL values were not available, reaction rates from the NIST database were used (see Table S1). We also derive temperature-dependent wall loss constants for $\mathrm{O}$ and $\mathrm{OH}$ using the procedure outlined by Thieser et al. (2016), but we find that better agreement in some simulations can be achieved with the experimental data by using an empirical value or no wall loss at all. As can 
be seen in Sect. 3, these simulations successfully replicated a major portion, but not all, of the experimental results, likely due to these simplifications.

\section{Results}

\section{1 $\mathrm{HNO}_{3}$ thermograms}

Figure 2 shows the conversion efficiency of $\mathrm{HNO}_{3}$ to $\mathrm{NO}_{2}$ as a function of temperature for several flow rates through the NOAA TD-CRDS. Conversion efficiency was calculated as the measured $\mathrm{NO}_{2}$ mixing ratio divided by the input $\mathrm{HNO}_{3}$ mixing ratio. The box model simulations for each flow rate are shown as solid lines of corresponding color. The $\mathrm{HNO}_{3}$ permeation tube has a calibrated output of $64 \mathrm{ng} \mathrm{min}{ }^{-1}$, which corresponds to an expected $\mathrm{HNO}_{3}$ concentration of between 5 and $40 \mathrm{ppbv}$, depending on the zero air dilution required for each flow rate. The output of the permeation tube was found to contain approximately $2.5 \% \mathrm{NO}_{2}$, and all $\mathrm{HNO}_{3}$ thermograms have had this $2.5 \%$ baseline signal subtracted. At a flow rate of $1.9 \mathrm{slpm}$ (where the oven residence time is $30-100 \mathrm{~ms}$ depending on temperature), we observe $100 \%$ conversion of $\mathrm{HNO}_{3}$ at oven temperatures above $600^{\circ} \mathrm{C}$, whereas the thermograms obtained at 1 and $3 \mathrm{slpm}$ reach a maximum conversion of $100 \%$ at 550 and $650^{\circ} \mathrm{C}$, respectively. The $0.5 \mathrm{slpm}$ thermogram has a slightly lower maximum conversion efficiency ( $95 \%$ ), possibly due to the recombination reaction of $\mathrm{OH}$ and $\mathrm{NO}_{2}$ during the extended time in the "cooling region" prior to detection.

The box model simulations in Fig. 2 mimic the shape of the experimental data, but some are slightly shifted to higher or lower temperatures, likely because the simulation is extremely sensitive to the flow rate and may be affected by the simplifying assumptions detailed in Sect. 2.4. The shape of the simulated thermogram is entirely controlled by the reaction rate of the initial dissociation reaction of $\mathrm{HNO}_{3}$ to $\mathrm{NO}_{2}+\mathrm{OH}$. This reaction has a third-order rate constant of $k_{0}(T)=1.82 \times 10^{-4} \times(T / 298)^{-1.98} \times e^{(-24004 / T)}$ and a high-pressure limit of $k_{\infty}(T)=2 \times 10^{15} \times e^{(-24054 / T)}$ (Glänzer and Troe, 1974), and thus at a midrange temperature, such as $500^{\circ} \mathrm{C}$, the $\mathrm{HNO}_{3}$ lifetime is approximately $250 \mathrm{~ms}$. The inner volume of the oven is $4.5 \mathrm{~cm}^{3}$, and so at a flow rate of $1.9 \mathrm{slpm}$, the gas has a plug flow residence time of $38 \mathrm{~ms}$ in the $500^{\circ} \mathrm{C}$ oven, compared to a residence time of $77 \mathrm{~ms}$ at $1.0 \mathrm{slpm}$ and $153 \mathrm{~ms}$ at $0.5 \mathrm{slpm}$. The simulated conversion efficiency in these midrange temperatures is therefore extremely sensitive to the flow rate, in agreement with our experimental results. However, the experimental $100 \%$ conversion efficiency at high temperatures indicates that there is virtually no recombination of $\mathrm{OH}$ and $\mathrm{NO}_{2}$ once formed, because the recombination rate for $\mathrm{OH}+\mathrm{NO}_{2}$ is quite low and because $\mathrm{OH}$ radicals are far more likely to be lost to the walls of the oven at a diffusion-limited rate determined by Day et al. (2002) of

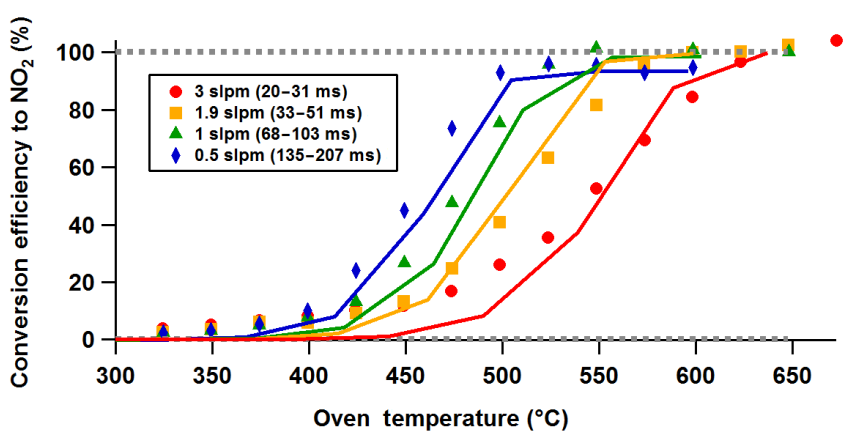

Figure 2. $\mathrm{HNO}_{3}$ thermograms measured at several flow rates in the NOAA TD-CRDS. Conversion efficiency is calculated as measured $\mathrm{NO}_{2}$ signal relative to the expected concentration of $\mathrm{HNO}_{3}$. Parentheses in the legend indicate the range of residence times experienced by the sample in the heated inlet. The grey dashed lines indicate 0 and $100 \%$ conversion. Solid lines show simulations using a simple kinetic box model, as described in the text.

$\sim 46 \mathrm{~s}^{-1}$ for $1 / 4$ in $(0.63 \mathrm{~cm})$ OD tubing, which is far higher than the pseudo-first-order recombination rate coefficient of $0.075 \mathrm{~s}^{-1}$ at $\left[\mathrm{NO}_{2}\right]=10 \mathrm{ppbv}$. No attempt was made to dilute the output of the $\mathrm{HNO}_{3}$ permeation tube any further, as recombination effects would likely only be less important at lower starting $\mathrm{HNO}_{3}$ concentrations. Similarly, increasing the starting $\mathrm{NO}_{2}$ concentration, to mimic conditions in highly polluted environments, was not attempted in this set of experiments, but increasing the starting $\mathrm{NO}_{2}$ concentration in the kinetic model up to $50 \mathrm{ppbv}$ shows that there is no recombination expected even with elevated $\mathrm{NO}_{2}$ in the oven. This is in contrast to ANs and PNs, for which the reaction of the dissociated peroxy and alkyl radicals with $\mathrm{NO}_{2}$ is a significant interference (Thieser et al., 2016), but in good agreement with the $\mathrm{HNO}_{3}$ results of Day et al. (2002) and Sobanski et al. (2016).

At a flow rate of $1.9 \mathrm{slpm}$, we observe a $\sim 6 \%$ conversion of $\mathrm{HNO}_{3}$ to $\mathrm{NO}_{2}$ at an oven temperature of $400^{\circ} \mathrm{C}$. Although this efficiency is specific to the conditions of the oven used here, it is a key finding since $400^{\circ} \mathrm{C}$ is in the vicinity of the temperature set point chosen for selective detection of total alkyl and multifunctional nitrates by TD-LIF (Day et al., 2002) and other TD instruments. This result is in good agreement with Thieser et al. (2016), who found a $\sim 10 \%$ $\mathrm{HNO}_{3}$ conversion at $450{ }^{\circ} \mathrm{C}$. Sadanaga et al. (2016) report a $\sim 15 \% \mathrm{HNO}_{3}$ conversion at $360^{\circ} \mathrm{C}$ at a TD residence time of $3.4 \mathrm{~s}$, which exceeds the range of our study but follows the trend in Fig. 3. In a previous study (Wild et al., 2014), we presented thermograms designed to demonstrate quantitative conversion efficiency at high temperatures. The temperature dependence of thermal conversion was not well constrained at lower temperatures and showed, for example, $30 \%$ conversion at $400^{\circ} \mathrm{C}$. As discussed by Sobanski et al. (2016), the large conversion efficiency presented by Wild et al. (2014) at this temperature is likely incorrect. The extent of $\mathrm{HNO}_{3}$ con- 


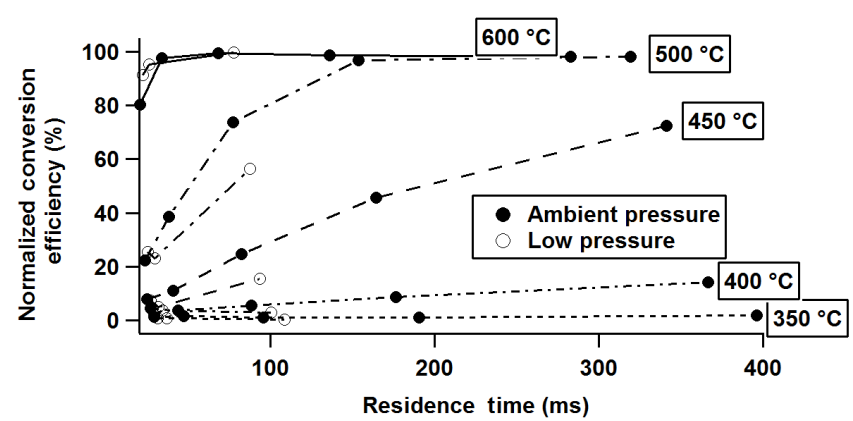

Figure 3. Conversion efficiencies of $\mathrm{HNO}_{3}$ to $\mathrm{NO}_{2}$ plotted as a function of plug flow residence times in the oven (see text) for five different temperatures. Values were obtained by scaling the measured conversion efficiency in Fig. 1 to the overall maximum and minimum of the thermogram, to account for slight differences between thermograms. Solid circles indicated measurements at ambient pressure, whereas open circles indicate measurements at low pressure. Different line traces indicated different temperatures. A temperature set point between 350 (short dashed line) and $450^{\circ}$ (long dashed line) and a residence time less than $200 \mathrm{~ms}$ are the conditions normally selected for selective detection of alkyl nitrates with no detection of $\mathrm{HNO}_{3}$. However, under these conditions $\mathrm{HNO}_{3}$ conversion may be anywhere between 1 and $30 \%$.

version is dependent on the residence time in the oven, but because residence time for a given flow rate changes with oven temperature, it is easier to observe this effect by plotting conversion efficiency versus residence time, as in Fig. 3, for five different temperatures $\left(350,400,450,500\right.$, and $\left.600^{\circ} \mathrm{C}\right)$. This plot represents transects through Fig. 2 at these five temperatures. Figure S2 shows a log scale plot to highlight the low conversion efficiency region. Most instruments utilizing the TD oven technique use a set point between 350 and $450^{\circ}$ and a residence time between 30 and $100 \mathrm{~ms}$ to selectively detect ANs and not $\mathrm{HNO}_{3}$ (Day et al., 2003; Paul et al., 2009; Thieser et al., 2016), but Fig. 3 demonstrates that there is significant variability in the $\mathrm{HNO}_{3}$ conversion efficiency that depends nonlinearly on oven residence time.

We further measure the effect of pressure on the conversion by placing a heated stainless steel needle valve in front of the oven, thus lowering the pressure inside the oven to 250 mbar. The low pressure transects for each of the five temperatures can be seen in open circles in Fig. 3, and the full thermograms are displayed in Fig. S3. The low pressure transects are slightly lower than those at ambient pressure for the 450 and $500^{\circ} \mathrm{C}$ set points but match reasonably well at low and high temperatures, indicating that the onset and final conversion of $\mathrm{HNO}_{3}$ are not strongly sensitive to pressure. To ensure that $\mathrm{HNO}_{3}$ was not lost on the walls of the stainless steel valve, the conversion efficiency was measured with the valve fully open and was found to match that taken with no valve. These experiments demonstrate the importance of verifying that a given temperature set point and that flow rate is suitable for measurement of alkyl nitrates without interference from $\mathrm{HNO}_{3}$ conversion.

To demonstrate the variability within individual TD ovens, an example of the $\mathrm{HNO}_{3}$ conversion efficiency near the alkyl nitrate temperature set point, as measured by the Berkeley TD-LIF instrument, is shown in Fig. 4. This inlet's alkyl nitrate set point temperature was chosen to be just past the plateau in the $n$-propyl nitrate signal at $410^{\circ} \mathrm{C}$. The $\mathrm{HNO}_{3}$ conversion to $\mathrm{NO}_{2}$ was found to be $2.5 \%$, which for most TD-LIF experiments would be negligible compared to other uncertainties in measured ANs $( \pm 15 \%)$ and no correction would be applied. One example where a correction was significant was for the NASA DISCOVER-AQ California deployment, which took place in California's central valley during a period of high $\mathrm{NH}_{4} \mathrm{NO}_{3}$ aerosol loading. Ratios of $\left(\mathrm{HNO}_{3}+\mathrm{NH}_{4} \mathrm{NO}_{3}\right)$ to ANs were high enough that a correction was necessary and applied to both observations (Pusede et al., 2016). As $\mathrm{HNO}_{3}$ is derived by subtraction of the ANs, any $\mathrm{HNO}_{3}$ conversion at the $\mathrm{AN}$ temperature results in a high bias for ANs and an equal low bias for $\mathrm{HNO}_{3}$. The sum of the two remains correct, independent of the onset of the $\mathrm{HNO}_{3}$ conversion. The Berkeley group has found the $\mathrm{HNO}_{3}$ conversion to be oven dependent even for identical pressure and flow conditions, indicating that some but not all ovens have impurities at the walls that effectively catalyze $\mathrm{HNO}_{3}$ decomposition. Ovens with high $\mathrm{HNO}_{3}$ conversion efficiencies at low temperatures were discarded. These results highlight the importance of careful evaluation and calibration of each TD oven, even when the inner volumes and flow rates are similar.

\section{2 $\mathrm{HNO}_{3}$ thermograms with additions}

Tests for other interferences to $\mathrm{HNO}_{3}$ and $\mathrm{AN}$ measurements included adding several different chemical species to the $\mathrm{HNO}_{3}$ sample prior to entering the oven. These were designed to test the hypothesis that certain trace gases found in ambient air would interact with radicals in the oven or would themselves dissociate to form radicals which could react with $\mathrm{NO}, \mathrm{NO}_{2}, \mathrm{OH}$, or $\mathrm{HNO}_{3}$. The results are shown in Fig. 5. In Fig. 5a, a portion of the dilution air was passed through a distilled water bubbler prior to diluting the $\mathrm{HNO}_{3}$, bringing the relative humidity up to $66 \%$. The change in $\mathrm{RH}$ does not alter the shape, onset, or total conversion efficiency of the thermogram. This is to be expected, as the oven temperature is not high enough to dissociate $\mathrm{H}_{2} \mathrm{O}$ to $\mathrm{OH}+\mathrm{H}$, and reactions between $\mathrm{H}_{2} \mathrm{O}$ and the relevant species formed in the oven from $\mathrm{HNO}_{3}$ dissociation are far too slow to be important here. However, it should be noted that both $\mathrm{H}_{2} \mathrm{O}$ and $\mathrm{HNO}_{3}$ are sampled in this experiment at a steady concentration, and it is possible that, during ambient sampling, rapid changes in the $\mathrm{RH}$ or $\mathrm{HNO}_{3}$ concentration could change the overall efficiency. Additionally, we did not test the conversion efficiency at very high RH levels, and it is possible there could be a nonlinear effect of water. Figure $5 \mathrm{~b}$ shows the 


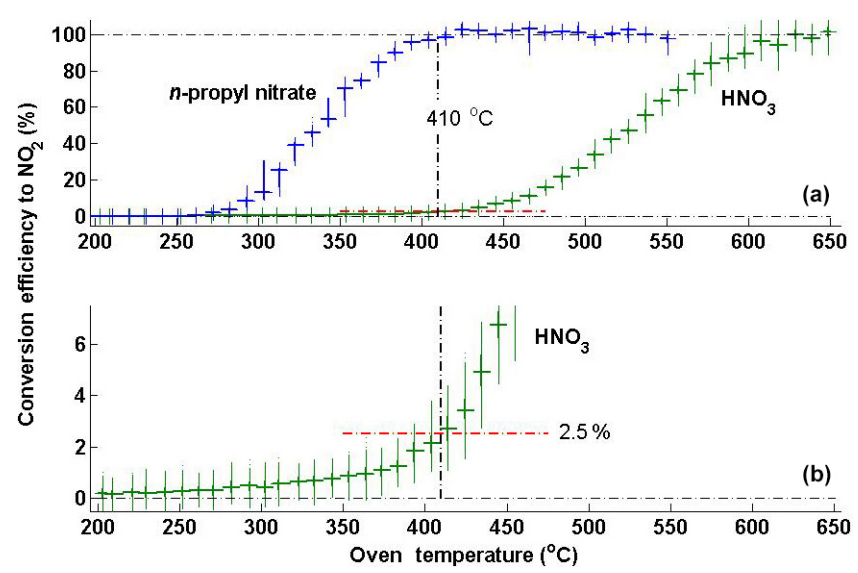

Figure 4. $\mathrm{HNO}_{3}$ and $n$-propyl nitrate thermograms taken with the Berkeley TD-LIF instrument used in the NASA DISCOVER-AQ California mission. (b) Only $\mathrm{HNO}_{3}$ with the $y$ axis expanded to illustrate the dissociation onset. The oven is from the instrument's alkyl nitrates channel. The flow rate was approximately $2 \mathrm{slpm}$, and the measurement set point was $410^{\circ} \mathrm{C}$. The dataset was corrected for the $2.5 \%$ dissociation of $\mathrm{HNO}_{3}$ in the alkyl nitrates channel. A different oven was used for $\mathrm{HNO}_{3}$ at a set point of $620^{\circ} \mathrm{C}$.

measured thermogram with the addition of $\sim 50 \mathrm{ppbv}$ VOCs (described in Sect. 2.2) with and without the addition of $90 \mathrm{ppbv} \mathrm{O}_{3}$ as well as the addition of $5 \mathrm{ppmv}$ of propane, to mimic conditions found in highly polluted wintertime atmospheres. If organic radicals were produced thermally in the TD oven, they could potentially react with $\mathrm{NO}_{2}$, thus altering that signal. However, the bond dissociation energy of the $\mathrm{C}-\mathrm{H}$ or $\mathrm{C}-\mathrm{C}$ bonds most likely to thermally dissociate in each of the VOCs are all significantly higher (typically $>100 \mathrm{kcal} \mathrm{mol}^{-1}$ ) than that of the $\mathrm{O}-\mathrm{N}$ bond in $\mathrm{HNO}_{3}$ $\left(\sim 50 \mathrm{kcal} \mathrm{mol}^{-1}\right)$, making it unlikely that organic radicals are formed inside the oven from dissociation of VOCs. Reactions of unsaturated hydrocarbons with $\mathrm{O}$ atoms or $\mathrm{OH}$ radicals tend to be rapid and would produce organic radicals, but these tend to be unstable, and any stable radicals would likely only react with $\mathrm{NO}_{2}$ to form ANs or PNs. The oven is set at sufficiently high temperatures to dissociate ANs and PNs back to $\mathrm{NO}_{2}+$ the organic radical. Addition of these VOCs does not affect the measured conversion efficiency, even in the presence of ambient levels of $\mathrm{O}_{3}$. Ozonolysis of the unsaturated hydrocarbons is slow enough (typically on the order of $1 \times 10^{-17} \mathrm{~cm}^{3}$ molecule $\left.{ }^{-1} \mathrm{~s}^{-1}\right)$ to not have any effect here (we would expect $<0.0001 \%$ reaction for the duration of the oven residence time). An extremely high concentration of propane also has no effect on the overall conversion efficiency, within the error bars of the measurement, for the same reasons as detailed above.

Figure $5 \mathrm{c}$ shows the addition of both small and large quantities of $\mathrm{O}_{3}$ to the $\mathrm{HNO}_{3}$ sample. Small quantities do not change the onset or overall conversion efficiency, but larger amounts of $\mathrm{O}_{3}$ reduce the conversion efficiency at high tem-

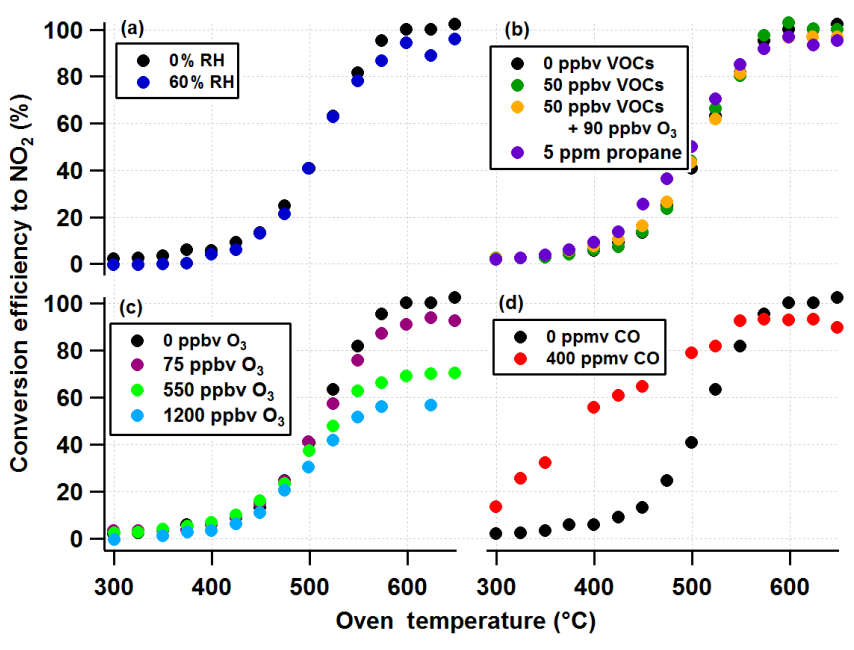

Figure 5. $\mathrm{HNO}_{3}$ thermograms (1.9 slpm, ambient pressure) taken with the NOAA TD-CRDS, with various additions added prior to the TD oven. In each frame, the black solid circles indicate the case without additions. (a, b) No effect is observed when the thermogram is taken at high relative humidity or when VOCs are added. (c) Varying amounts of $\mathrm{O}_{3}$ were added, ranging from ambient levels ( $75 \mathrm{ppbv})$ to extremely polluted levels (1200 ppbv), which decreases the overall conversion at high temperatures. (d) The addition of $400 \mathrm{ppmv} \mathrm{CO}$ alters the shape of the thermogram.

peratures. The kinetic box model does not predict this reduction, as it predicts $100 \%$ conversion efficiency to $\mathrm{NO}_{2}$ at all $\mathrm{O}_{3}$ levels. The dominant bimolecular reaction of $\mathrm{O}_{3}$ in the model is the reaction with $\mathrm{NO}_{2}$ to make $\mathrm{NO}_{3}$, but, since these reactions are occurring at high temperature, any $\mathrm{NO}_{3}$ formed will immediately dissociate to $\mathrm{NO}_{2}$ (see Sect. 3.3). $\mathrm{O}_{3}$ also thermally dissociates to $\mathrm{O}+\mathrm{O}_{2}$ at temperatures above $200^{\circ} \mathrm{C}$ (see Fig. S4), but the dominant fate of the $\mathrm{O}$ radicals should be loss to the walls. Of the $\mathrm{O}$ atoms that are not lost to the walls, their primary reaction is also with $\mathrm{NO}_{2}$ to form either $\mathrm{NO}+\mathrm{O}_{2}$ or $\mathrm{NO}_{3}$, but $\mathrm{NO}$ should be converted back to $\mathrm{NO}_{2}$ after the oven. Nevertheless, there is an apparent reduction in the conversion of $\mathrm{HNO}_{3}$ to $\mathrm{NO}_{2}$ with increasing $\mathrm{O}_{3}$. While the $\mathrm{O}_{3}$ concentration range in Fig. 5c exceeds that found in ambient air, highly polluted areas may have large enough $\mathrm{O}_{3}$ concentrations to make this reduction in conversion efficiency significant. Finally, the addition of $400 \mathrm{ppmv}$ $\mathrm{CO}$ in Fig. 5d has a marked effect on the onset, shape, and final conversion of the $\mathrm{HNO}_{3}$. This addition was tested because gold catalytic $\mathrm{NO}_{y}$ converters require a $1 \% \mathrm{CO}$ addition to drive the dissociation forward. We find that $\sim 0.5 \%$ $\mathrm{CO}$ is sufficient to promote $\mathrm{HNO}_{3}$ dissociation even in the absence of a gold catalyst. However, our kinetic model does not replicate the results of the $\mathrm{CO}$ addition. Since the ratelimiting step in these thermograms is the initial dissociation of $\mathrm{HNO}_{3}$, it is unlikely that the reaction between $\mathrm{CO}$ and $\mathrm{OH}$ or $\mathrm{NO}_{2}$ plays a role here. It must therefore be caused by a reaction which changes the rate kinetics of the initial dis- 
sociation step. However, to our knowledge there have been no laboratory kinetics studies on the $\mathrm{CO}+\mathrm{HNO}_{3}$ reaction. It is likely that there is some surface reaction that affects the $\mathrm{HNO}_{3}$ conversion in the presence of $\mathrm{CO}$.

We also note that previous work on TD ovens (Day et al., 2002; Thieser et al., 2016) has cautioned that the elevated temperature of the oven may accelerate the reaction between ambient levels of $\mathrm{NO}$ and $\mathrm{O}_{3}$ to generate $\mathrm{NO}_{2}$, thereby creating an $\mathrm{NO}_{2}$ signal that is in fact due to ambient levels of NO. This issue does not affect the TD-CRDS $\mathrm{NO}_{y}$ detection scheme, as excess $\mathrm{O}_{3}$ is intentionally added to the mixing volume after the oven to convert $\mathrm{NO}$ to $\mathrm{NO}_{2}$ to measure total $\mathrm{NO}_{y}$. Nevertheless, we have investigated how NO responds in the oven, and the results are shown in Fig. S5. A 15 ppbv $\mathrm{NO}$ sample was passed through the oven. When no excess $\mathrm{O}_{3}$ is added to the mixing volume, no $\mathrm{NO}_{2}$ signal is seen, and, when mixing volume $\mathrm{O}_{3}$ is added, full conversion of $\mathrm{NO}$ to $\mathrm{NO}_{2}$ is observed, as expected. However, when $100 \mathrm{ppbv}$ of $\mathrm{O}_{3}$ is added to the oven (with no mixing volume $\mathrm{O}_{3}$ addition), an approximately 2.2 ppbv $\mathrm{NO}_{2}$ signal was observed, or a $15 \%$ conversion. This is consistent with the kinetic rate expressions for $\mathrm{NO}+\mathrm{O}_{3}$ and $\mathrm{NO}+\mathrm{O}$, but we do not differentiate between these two mechanisms in these experiments, as $\mathrm{O}_{3}$ will always form $\mathrm{O}$ at the elevated oven temperatures.

\section{3 $\quad \mathrm{N}_{2} \mathrm{O}_{5}$ thermograms}

Figure 6 shows the measured thermogram of $\mathrm{N}_{2} \mathrm{O}_{5}$ in the NOAA TD-CRDS at ambient pressure and flow rates of 1.9 and $1.0 \mathrm{slpm}$, with the kinetic model simulations for each flow rate shown in solid and dashed lines. Two distinct dissociation steps are observed and confirmed by the kinetic model: one between 30 and $110^{\circ} \mathrm{C}$ corresponding to the dissociation of $\mathrm{N}_{2} \mathrm{O}_{5}$ to $\mathrm{NO}_{2}+\mathrm{NO}_{3}$ and one above $300^{\circ} \mathrm{C}$ corresponding to the dissociation of $\mathrm{NO}_{3}$. The $\mathrm{N}_{2} \mathrm{O}_{5}$ synthesis method also produces $\mathrm{HNO}_{3}$ (Bertram et al., 2009), and, because the bond enthalpies of $\mathrm{NO}_{3}$ and $\mathrm{HNO}_{3}$ dissociation are similar (both $\sim 50 \mathrm{kcal} \mathrm{mol}^{-1}$ ), the thermograms of these two species are expected to overlap at high temperatures. Thus, a nylon wool scrubber was used to remove $\mathrm{HNO}_{3}$, and the scrubbed sample was simultaneously monitored with an iodide chemical ionization mass spectrometer, described in Sect. 2.3, to ensure the $\mathrm{HNO}_{3}$ (and not the $\mathrm{N}_{2} \mathrm{O}_{5}$ ) was completely removed. The flow rate was lowered to $1.0 \mathrm{slpm}$ in the high temperature scans to accommodate both instruments with a better signal-to-noise ratio. The CIMS measured approximately $120 \mathrm{pptv} \mathrm{HNO}_{3}$, possibly due to hydrolysis of $\mathrm{N}_{2} \mathrm{O}_{5}$ after the scrubber, and thus more than $99.5 \%$ of the $\mathrm{NO}_{2}$ signal we observe is attributed to $\mathrm{N}_{2} \mathrm{O}_{5}$.

At high temperatures, each $\mathrm{N}_{2} \mathrm{O}_{5}$ is expected to produce two $\mathrm{NO}_{2}$ molecules. Conversion efficiency is calculated from the measured $\mathrm{NO}_{2}$ concentration relative to the $\mathrm{N}_{2} \mathrm{O}_{5}$ concentration measured by the CIMS instrument, which samples prior to the TD oven. However, the CIMS instrument requires an empirical calibration factor for any species it measures,

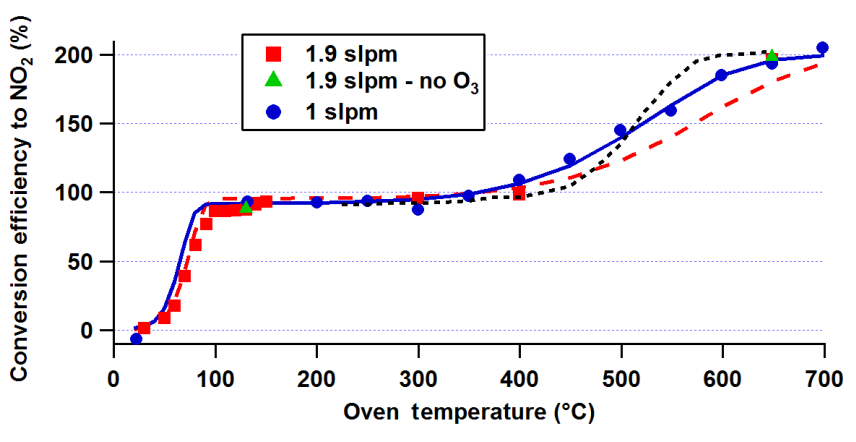

Figure 6. Thermogram of $\mathrm{N}_{2} \mathrm{O}_{5}$ measured in the NOAA TD-CRDS at two flow rates. The red squares and red dashed line show the $1.9 \mathrm{slpm}$ thermogram and simulation, while the blue circles and blue solid line show the analogous result at $1.0 \mathrm{slpm}$. The first dissociation corresponds to $\mathrm{N}_{2} \mathrm{O}_{5} \rightarrow \mathrm{NO}_{2}+\mathrm{NO}_{3}$ and the second to $\mathrm{NO}_{3} \rightarrow \mathrm{NO}_{2}+\mathrm{O}$. The second curve reaches a maximum of $200 \%$, while the first reaches $90-95 \%$, depending on the flow rate, due to recombination of $\mathrm{NO}_{2}$ and $\mathrm{NO}_{3}$ in the cooling region prior to the detector region. The black dashed line is the experimental $\mathrm{HNO}_{3}$ thermogram from Fig. 2, offset by $100 \%$. The green triangles indicate measurements of the conversion efficiency without the $\mathrm{O}_{3}$ addition, confirming that the second dissociation must occur via $\mathrm{NO}_{3} \rightarrow \mathrm{NO}_{2}+\mathrm{O}$ rather than $\mathrm{NO}_{3} \rightarrow \mathrm{NO}+\mathrm{O}_{2}$.

and, while the $\mathrm{HNO}_{3}$ signal may be calibrated using the permeation tube described in Sect. 3.1, there was no independent calibration available for $\mathrm{N}_{2} \mathrm{O}_{5}$ - only the signal measured using the TD-CRDS instrument. Therefore, the CIMS $\mathrm{N}_{2} \mathrm{O}_{5}$ signal was assumed to correspond to a $200 \%$ conversion efficiency in the TD-CRDS at $650{ }^{\circ} \mathrm{C}$, and the relative conversion was measured at lower temperatures. The first dissociation step of $\mathrm{N}_{2} \mathrm{O}_{5}$ to $\mathrm{NO}_{2}$ and $\mathrm{NO}_{3}$ is expected at oven temperatures above $110^{\circ} \mathrm{C}$, but, because the sample must then travel through a cooling region prior to entering the CRDS optical cavity (see Fig. 1), approximately $10 \%$ of the $\mathrm{NO}_{2}$ and $\mathrm{NO}_{3}$ is expected to recombine back to $\mathrm{N}_{2} \mathrm{O}_{5}$, based on the rate constant and the residence time in the mixing volume. This behavior has been well characterized previously (Fuchs et al., 2009) and is accounted for in the data analysis, and as expected we observe a $91 \%$ conversion efficiency of $\mathrm{N}_{2} \mathrm{O}_{5}$ to $\mathrm{NO}_{2}$ between 110 and $300^{\circ} \mathrm{C}$. At higher temperatures, $\mathrm{NO}_{3}$ dissociates in the oven before recombining with $\mathrm{NO}_{2}$, and thus a $200 \%$ conversion efficiency is observed. While this is not an absolute measure of conversion efficiency, the relative conversion efficiency is consistent with $\mathrm{N}_{2} \mathrm{O}_{5}$ dissociation and recombination reaction rates to generate two $\mathrm{NO}_{2}$ molecules in a distinct stepwise manner. At 150 and $400{ }^{\circ} \mathrm{C}$, the temperature set points often used for detection of PANs and ANs, we find 90 and $105 \%$ conversion of $\mathrm{N}_{2} \mathrm{O}_{5}$ to $\mathrm{NO}_{2}$, respectively. The exact values are highly dependent on the residence time in both the oven and in the cooling region but serve to highlight the importance of characterizing the $\mathrm{N}_{2} \mathrm{O}_{5}$ response in every thermal dissociation oven. 
We also measured the conversion of $\mathrm{N}_{2} \mathrm{O}_{5}$ without the mixing volume $\mathrm{O}_{3}$ addition at two relevant temperatures in order to determine the mechanism for $\mathrm{NO}_{3}$ dissociation. These data are shown in green triangles in Fig. 6 and show no difference in onset or maximum conversion efficiency, whether or not mixing volume $\mathrm{O}_{3}$ is added. As the mixing volume $\mathrm{O}_{3}$ converts ambient or thermally produced $\mathrm{NO}$ to $\mathrm{NO}_{2}$, the similarity of the two spectra indicates that the $\mathrm{NO}_{3}$ dissociation mechanism must be $\mathrm{NO}_{3} \rightarrow \mathrm{NO}_{2}+\mathrm{O}$. However, there are no published rate expressions for this reaction, and the few studies on $\mathrm{NO}_{3}$ thermal dissociation have disagreed about whether the reaction proceeds to $\mathrm{NO}+\mathrm{O}_{2}$ (Johnston et al., 1986) or $\mathrm{NO}_{2}+\mathrm{O}$ (Schott and Davidson, 1958). The former argued for the $\mathrm{NO}_{3} \rightarrow \mathrm{NO}+\mathrm{O}_{2}$ mechanism based on thermodynamics, as this reaction is exothermic. However, this implies that $\mathrm{NO}_{3}$ would be thermally unstable at room temperature, which is not the case. It is likely that there is a significant energy barrier to this reaction. The bond enthalpy of the $\mathrm{NO}_{3} \rightarrow \mathrm{NO}_{2}+\mathrm{O}$ reaction, on the other hand, is $50.4 \mathrm{kcal} \mathrm{mol}^{-1}$, nearly identical to that of $\mathrm{HNO}_{3} \rightarrow \mathrm{NO}_{2}+\mathrm{OH}$, and the two thermograms are very similar in shape and are centered at the same temperature $\left(500^{\circ} \mathrm{C}\right)$. The simulation shown in Fig. 6 is a fit rate expression of $k(T)=1 \times 10^{-2} \times(T / 298)^{9} \times \exp (-1500 / T)$ obtained by taking the rate expression of $\mathrm{HNO}_{3}$ dissociation and iteratively adjusting it until it matched the data. Essentially identical results were observed in the TD-LIF instrument (R. C. Cohen, personal communication, 2016).

\section{4 $\mathrm{NH}_{4} \mathrm{NO}_{3}$ thermograms}

$\mathrm{NH}_{4} \mathrm{NO}_{3}$ particles were generated in situ from an aqueous solution, dried, and size selected by a differential mobility analyzer set at $250 \mathrm{~nm}$ prior to entering the TD oven. The conversion efficiency was calculated by comparing the measured $\mathrm{NO}_{2}$ concentration in the TD-CRDS instrument to the expected number of $\mathrm{NH}_{4} \mathrm{NO}_{3}$ molecules in the aerosol particles, derived from the number and size of the aerosol particles as measured with an ultra-high sensitivity aerosol spectrometer (UHSAS). The measured UHSAS histogram was used, along with the literature value for the density of $\mathrm{NH}_{4} \mathrm{NO}_{3}$, to convert particle diameter to particle volume and then to the total number of $\mathrm{NH}_{4} \mathrm{NO}_{3}$ molecules. We demonstrate here that the dissociation pathway is $\mathrm{NH}_{4} \mathrm{NO}_{3} \rightarrow \mathrm{NH}_{3}+\mathrm{HNO}_{3}$, and we assume that $\mathrm{NH}_{3}$ is not converted in any significant fraction. A temperaturedependent baseline $\mathrm{NO}_{2}$ signal is observed when the DMA voltage is set to zero (i.e. when no particles are transmitted), which is attributed to gas-phase $\mathrm{HNO}_{3}$ molecules which have evaporated from the particles and adsorbed to the tubing walls, and which are subtracted from the total signal. Figure 7 shows the measured thermogram of $\mathrm{NH}_{4} \mathrm{NO}_{3}$ with the thermogram of gas-phase $\mathrm{HNO}_{3}$ from Fig. 2 overlaid. The close agreement between the two thermograms demonstrates that the dissociation pathway is $\mathrm{NH}_{4} \mathrm{NO}_{3} \rightarrow \mathrm{NH}_{3}+\mathrm{HNO}_{3}$

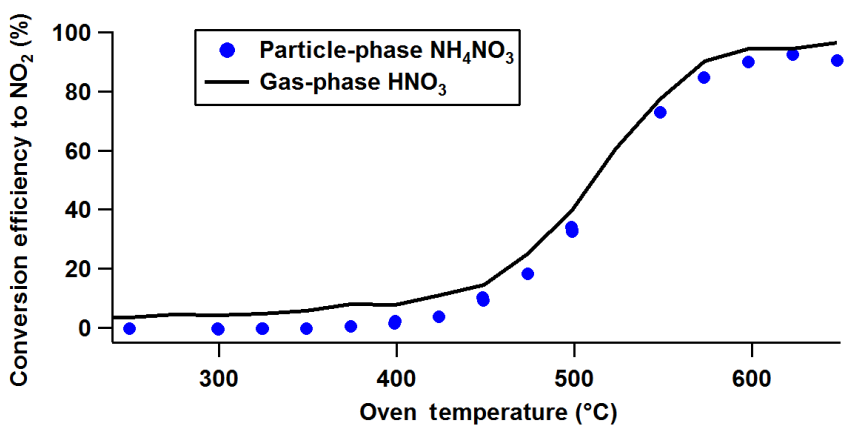

Figure 7. Measured thermogram of $\mathrm{NH}_{4} \mathrm{NO}_{3}$ particles as solid circles from the NOAA TD-CRDS. The black solid line indicates the measured thermogram of gas-phase $\mathrm{HNO}_{3}$ at a $1.9 \mathrm{slpm}$ flow rate (from the gold squares trace in Fig. 2). The close match of these two thermograms indicates that the $\mathrm{NH}_{4} \mathrm{NO}_{3}$ particles go through $\mathrm{HNO}_{3}$ as an intermediate and is a good indication that complete conversion is achieved.

and that this reaction is rapid at the temperatures reached in the TD inlet.

For particles that pass through the DMA at a given size set point, the UHSAS measures a size histogram that peaks at a diameter approximately $8 \%$ lower, likely because the $\mathrm{NH}_{4} \mathrm{NO}_{3}$ particles are slightly non-spherical, and therefore the electrical mobility diameter is slightly larger than the geometric diameter. This phenomenon has been discussed at length elsewhere (DeCarlo et al., 2004), and we make no attempt to further characterize $\mathrm{NH}_{4} \mathrm{NO}_{3}$ particle behavior in the DMA - we have simply taken the UHSAS histogram data to calculate the particle volume, even though this is also subject to slight differences based on the refractive index of $\mathrm{NH}_{4} \mathrm{NO}_{3}$. However, if the TD oven were to fail to volatilize and convert all $\mathrm{NH}_{4} \mathrm{NO}_{3}$ particles to $\mathrm{HNO}_{3}$ and then to $\mathrm{NO}_{2}$, the measured thermogram would deviate from the $\mathrm{HNO}_{3}$ spectrum at lower temperatures, where perhaps the heat is not sufficient to drive the $\mathrm{NH}_{4} \mathrm{NO}_{3}$ out of the condensed phase. The close match between the two is a good indication that the conversion goes to completion. Additionally, Figs. S6 and S7 show a sample $\mathrm{NO}_{2}$ measurement measured by TD-CRDS at $650^{\circ} \mathrm{C}$ as the particle diameter set point is changed. There is no correlation between particle size and conversion efficiency, indicating that the oven is completely converting all particles without a size dependence.

\section{5 $\mathrm{NH}_{3}$ thermograms}

A previous study (Wild et al., 2014) investigated whether ambient levels of ammonia would represent an interference to $\mathrm{NO}_{y}$ conversion and found that it made at most a $1 \%$ difference to the $\mathrm{NO}_{2}$ signal in dry air, but that this effect was suppressed when $\mathrm{RH}>10 \%$. We find in the present study that there is a significant interference when ambient levels of both $\mathrm{NH}_{3}$ and $\mathrm{O}_{3}$ are present in the oven, but that this effect is potentially suppressed by other species found in am- 
bient sampling. Figure 8 shows a thermogram of $\mathrm{NH}_{3}$ with and without $100 \mathrm{ppbv} \mathrm{O}_{3}$ present in the oven. The conversion of $\mathrm{NH}_{3}$ to $\mathrm{NO}_{2}$ at $650^{\circ} \mathrm{C}$, calculated as the observed $\mathrm{NO}_{2}$ signal relative to the added $\mathrm{NH}_{3}$ concentration, is small without $\mathrm{O}_{3}$. This is consistent with the previous study of Wild et al. (2014). However, when 100 ppbv of $\mathrm{O}_{3}$ is added, the thermogram reaches a maximum molar conversion efficiency of $8 \%$, with an onset near $400{ }^{\circ} \mathrm{C}$ (red circles). In contrast to the $\mathrm{HNO}_{3}$ thermograms, however, this signal does not appear to plateau at $650^{\circ} \mathrm{C}$ but rather continues to grow at higher temperatures. This result is similar to the interference reported by Dillon et al. (2002), which was attributed to a reaction between $\mathrm{NH}_{3}$ and $\mathrm{O}_{3}$. The interference is only present when $\mathrm{O}_{3}$ is added to the mixing volume, indicating that the conversion of $\mathrm{NH}_{3}$ must be producing $\mathrm{NO}$, rather than $\mathrm{NO}_{2}$, and is subsequently unimportant to instruments that measure $\mathrm{NO}_{2}$ only, such as TD-LIF instruments. A kinetic model simulation of both experiments is shown in solid lines in Fig. 8. This simulation was carried out with 35 relevant reactions between $\mathrm{NH}_{3}, \mathrm{O}_{3}$, and the radicals that are formed from these two species in the oven, with the most important reactions listed below. The reaction between $\mathrm{NH}_{3}$ and $\mathrm{O}_{3}$ is far too slow to be relevant here, and the oven temperature is not high enough to dissociate $\mathrm{NH}_{3}$ to $\mathrm{NH}_{2}+\mathrm{H}$ $\left(\Delta \mathrm{H}=108 \mathrm{kcal} \mathrm{mol}^{-1}\right)$. However, $\mathrm{O}_{3}$ dissociates readily at oven temperatures above $200^{\circ} \mathrm{C}$, and once formed the $\mathrm{O}$ atoms may react with $\mathrm{NH}_{3}$ to form $\mathrm{NH}_{2}$.

$\mathrm{O}_{3} \rightarrow \mathrm{O}_{2}+\mathrm{O}$

$\mathrm{NH}_{3}+\mathrm{O} \rightarrow \mathrm{NH}_{2}+\mathrm{OH}$

$\mathrm{NH}_{3}+\mathrm{OH} \rightarrow \mathrm{NH}_{2}+\mathrm{H}_{2} \mathrm{O}$

The reactions of $\mathrm{NH}_{3}$ are the slowest steps, but once formed $\mathrm{NH}_{2}$ reacts readily with $\mathrm{O}$ atoms.

$$
\begin{aligned}
\mathrm{NH}_{2}+\mathrm{O} & \rightarrow \mathrm{HNO}+\mathrm{H} \\
& \rightarrow \mathrm{OH}+\mathrm{NH} \\
& \rightarrow \mathrm{NO}+\mathrm{H}_{2}
\end{aligned}
$$

HNO then reacts with $\mathrm{O}, \mathrm{OH}$, and $\mathrm{H}$ to form $\mathrm{NO}$ or can also directly dissociate to form $\mathrm{H}+\mathrm{NO}$.

$$
\begin{aligned}
& \mathrm{HNO}+\mathrm{O} \rightarrow \mathrm{OH}+\mathrm{NO} \\
& \mathrm{HNO}+\mathrm{OH} \rightarrow \mathrm{H}_{2} \mathrm{O}+\mathrm{NO} \\
& \mathrm{HNO}+\mathrm{H} \rightarrow \mathrm{H}_{2}+\mathrm{NO} \\
& \mathrm{HNO} \rightarrow \mathrm{H}+\mathrm{NO}
\end{aligned}
$$

The $\mathrm{OH}$ and $\mathrm{H}$ atoms formed in reactions (R3) and (R4) then drive Reaction (R2) further. This mechanism takes place entirely in the gas phase and does not take into account any surface-mediated reactions. Many of these reactions have only limited published studies, so the simulation used rate constants that have not been extensively tested. Additionally, to achieve a significant conversion of $\mathrm{NH}_{3}$ to $\mathrm{NO}$, it

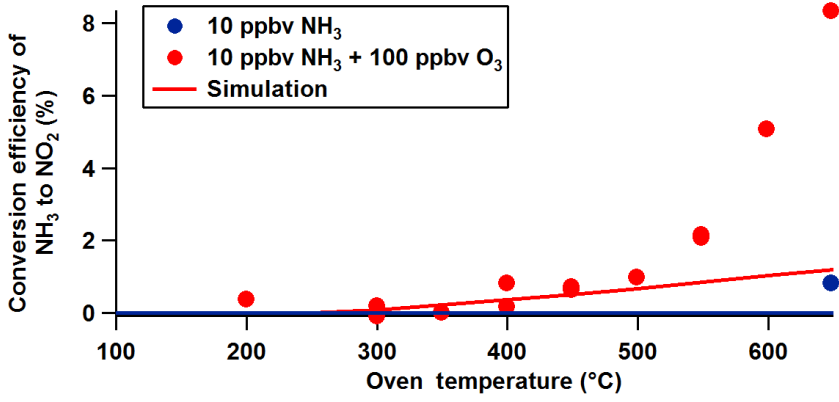

Figure 8. Thermogram of $\mathrm{NH}_{3}$ taken with the NOAA TD-CRDS, with $100 \mathrm{ppbv}$ of $\mathrm{O}_{3}$ added before the oven shown as red circles. The blue circle represents an analogous measurement at $650{ }^{\circ} \mathrm{C}$ with no $\mathrm{O}_{3}$ added. Kinetic box model simulations shown in solid lines of corresponding color.

was necessary to decrease the $\mathrm{O}$ and $\mathrm{OH}$ wall loss constants in the model. This rudimentary simulation predicts the initial signal increase starting at $300^{\circ} \mathrm{C}$, though it has a maximum conversion efficiency of just under $2 \%$, which is below that observed in the experiment. In Fig. 9, we adjusted the amount of added $\mathrm{O}_{3}$, while monitoring the conversion efficiency of $\mathrm{NH}_{3}$ to $\mathrm{NO}_{2}$ at an inlet temperature of $650^{\circ} \mathrm{C}$. We find that increasing the $\mathrm{O}_{3}$ increases the conversion, which is consistent with $\mathrm{NH}_{3}+\mathrm{O}$ being the limiting reaction to make $\mathrm{NH}_{2}$. Figure 9 also demonstrates that the conversion of $\mathrm{NH}_{3}$ is partially quenched by the addition of ambient levels $\left(\sim 100\right.$ ppbv) of $\mathrm{CO}$, likely because the $\mathrm{CO}+\mathrm{O} \rightarrow \mathrm{CO}_{2}$ reaction competes with those in Reaction (R2). Figure 10 shows that the average conversion efficiency of $\mathrm{NH}_{3}$ when measured in ambient air in Boulder, CO, in August 2016 (which contains 40-60 ppbv $\mathrm{O}_{3},>80$ ppbv $\mathrm{CO}, \sim 15 \% \mathrm{RH}$, and other species) is $0.5 \pm 2.4 \%$, or zero to within the $1 \sigma$ error from repeated measurements. This is in contrast to the conversion efficiency of $\mathrm{HNO}_{3}$ in ambient air, shown in the upper right frame of Fig. 10, which is largely unchanged from that measured in zero air. Thus, constituents present in ambient air, such as methane, $\mathrm{CO}$, and water, are possibly suppressing the conversion of $\mathrm{NH}_{3}$ to $\mathrm{NO}$, likely through the reaction with $\mathrm{O}$ atoms.

\section{Discussion}

Using a thermal dissociation cavity ring-down spectrometer, we have quantitatively added reactive nitrogen species to the TD inlet in order to test the efficiency of the thermal conversion of each species to $\mathrm{NO}_{2}$ and the effect of any interferences from other trace gases which may be present in the ambient troposphere. We have determined that the TDCRDS converts $\mathrm{HNO}_{3}, \mathrm{~N}_{2} \mathrm{O}_{5}$, and $\mathrm{NH}_{4} \mathrm{NO}_{3}$ particles to $\mathrm{NO}_{2}$ with $100 \%$ efficiency at temperatures above $600^{\circ} \mathrm{C}$, but that the onsets of the dissociation are highly dependent on oven residence time. Despite their similar residence times, the 


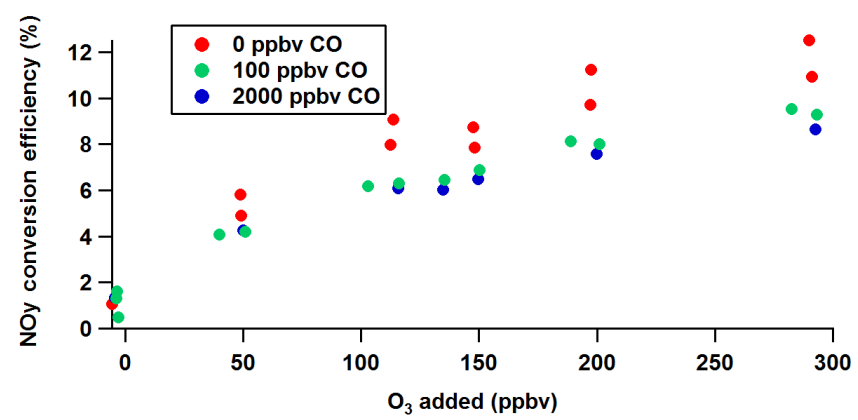

Figure 9. Conversion efficiency of $\mathrm{NH}_{3}$ to $\mathrm{NO}_{2}$ as a function of $\mathrm{O}_{3}$ added to the TD inlet. Red circles show 10 ppbv $\mathrm{NH}_{3}$ with $\mathrm{O}_{3}$ ranging from 0 to $300 \mathrm{ppbv}$, and the green and blue traces show similar data, but with 100 and 2000 ppbv CO added. The partial depletion of the signal $(\sim 25 \%)$ with the addition of CO indicates that the oxygen atoms formed from $\mathrm{O}_{3}$ pyrolysis are reacting with $\mathrm{CO}$ instead of $\mathrm{NH}_{3}$.

NOAA TD-CRDS and Berkeley TD-LIF instruments measure $\mathrm{HNO}_{3}$ conversion efficiencies ranging from 2.5 to $\sim 8 \%$ at $410^{\circ} \mathrm{C}$. It is therefore important that the oven residence time is well characterized in instruments designed to selectively detect ANs without interference from $\mathrm{HNO}_{3}$. Even two TD ovens with identical inner volumes may exhibit different response functions if they have different ratios of surface area to volume.

We find that high levels of ambient $\mathrm{O}_{3}(>500 \mathrm{ppbv})$ and $\mathrm{CO}(>400 \mathrm{ppmv})$ significantly changed the final conversion efficiency and the onset of the conversion, respectively, of the $\mathrm{HNO}_{3}$ thermogram but that ambient levels of a group of representative VOCs and high RH did not affect the measured thermogram. Modest levels of $\mathrm{O}_{3}$ converted a portion of $\mathrm{NH}_{3}$ to $\mathrm{NO}_{2}$. The conversion mechanism likely arises from a gas-phase reaction between oxygen atoms and $\mathrm{NH}_{3}$ which produces NO. To our knowledge, the $\mathrm{NH}_{3}+\mathrm{O}_{3}$ reaction in TD ovens has not been studied in detail, but previous studies of $\mathrm{NH}_{3}$ conversion in catalytic converters have noted similar results to those presented here - water and $\mathrm{CO}$ suppress the $\mathrm{NH}_{3}$ conversion to $\mathrm{NO}$, while $\mathrm{O}_{3}$ enhances it (Fahey et al., 1985; Kliner et al., 1997). If not quenched by other species present in ambient air, this effect could represent a potentially significant interference in field sampling for instruments that are sensitive to NO directly or via conversion to $\mathrm{NO}_{2}$. For example, at 50 ppbv $\mathrm{O}_{3}$, the $6 \%$ conversion of $\mathrm{NH}_{3}$ would present an interference of more than $10 \%$ if $\mathrm{NH}_{3} / \mathrm{NO}_{y}>1.7$, which is not an uncommon condition in agricultural regions. This signal was suppressed in ambient air, indicating that $\mathrm{NH}_{3}$ may not interfere with $\mathrm{NO}_{y}$ under most conditions. However, ambient air in Boulder is not representative of all sampling conditions, and, since the species responsible for quenching the reaction remains unclear, more work must be done to better understand the mechanism of the $\mathrm{NH}_{3} / \mathrm{O}_{3}$ thermal reaction. This result, along with the others detailed above, serves to emphasize that great care must be taken to characterize the potential interferences in $\mathrm{TD} \mathrm{NO}_{y}$ conversion ovens.

The measured $\mathrm{N}_{2} \mathrm{O}_{5}$ thermogram exhibits a double dissociation curve, corresponding to the initial dissociation of $\mathrm{N}_{2} \mathrm{O}_{5}$ to $\mathrm{NO}_{2}$ and $\mathrm{NO}_{3}$ and the subsequent dissociation of $\mathrm{NO}_{3}$. Our results indicate that the mechanism of the second step is $\mathrm{NO}_{3} \rightarrow \mathrm{NO}_{2}+\mathrm{O}$, in contrast to earlier literature that reported $\mathrm{NO}_{3} \rightarrow \mathrm{NO}+\mathrm{O}_{2}$ as the dominant mechanism. To our knowledge, this is the first published thermogram of $\mathrm{NO}_{3}$. TD-NO $\mathrm{NO}_{y}$ instruments often operate in the daytime when $\mathrm{N}_{2} \mathrm{O}_{5}$ is not a significant fraction of $\mathrm{NO}_{y}$, though some groups have operated at night and have typically assumed complete conversion to $\mathrm{NO}_{2}+\mathrm{NO}_{3}$ at the TD inlet set point for PNs (Di Carlo et al., 2013) and complete conversion to $2 \mathrm{NO}_{2}+\mathrm{O}$ at the set point for $\mathrm{HNO}_{3}$ (Wild et al., 2014). These results confirm that there is approximately quantitative conversion at these set points, though there are slight deviations from $100 \%$ conversion near the PN set point. Therefore, care must be taken to select a set point carefully and ensure complete conversion at that temperature. However, this interference would only be significant during nighttime or during very cold weather sampling.

The thermogram of particulate ammonium nitrate matches the thermogram of $\mathrm{HNO}_{3}$, within the margin of error of the UHSAS measurement. TD ovens have not typically been used explicitly for particle detection, with a few exceptions (Voisin et al., 2003; Smith et al., 2004; Rollins et al., 2010), though very fine particles may be sampled by the inlet, unless they are excluded aerodynamically or physically. These results demonstrate that the volatile portion of the particulate ammonium nitrates will be driven into the gas phase at low oven temperatures, consistent with Rollins et al. (2010), who used a denuder to remove gas-phase nitrates and to detect aerosol organic nitrates in a $325^{\circ} \mathrm{C}$ oven. Their results indicate it is likely that particulate organic nitrates would be converted to $\mathrm{NO}_{2}$ with $100 \%$ efficiency in the NOAA TDCRDS, but this result has not been explicitly tested here. Other $\mathrm{NO}_{3}$ salts might also be detected via thermal dissociation, although it is expected that they would be nonvolatile at the temperatures of these TD-inlets. Bertram and Cohen (2003) examined $\mathrm{NaNO}_{3}$ and determined that those particles would not be detected in TD inlets. However, these studies measured pure aerosols, and results may vary with heterogeneously mixed particles with multiple components. The initial dissociation of $\mathrm{NH}_{4} \mathrm{NO}_{3}$ will produce an $\mathrm{NH}_{3}$ molecule in addition to an $\mathrm{HNO}_{3}$ molecule, which means that particles may be subject to the same $\mathrm{NH}_{3} / \mathrm{O}_{3}$ interference when sampling in ambient air, which was not considered in this study. Additionally, the particles sampled in this paper were generated and injected directly into the inlet. The efficiency of particle sampling in ambient air will depend on particle size and inlet design, particularly during aircraft measurements. In future studies, a TD inlet that either effectively samples aerosol or effectively excludes aerosol (such 

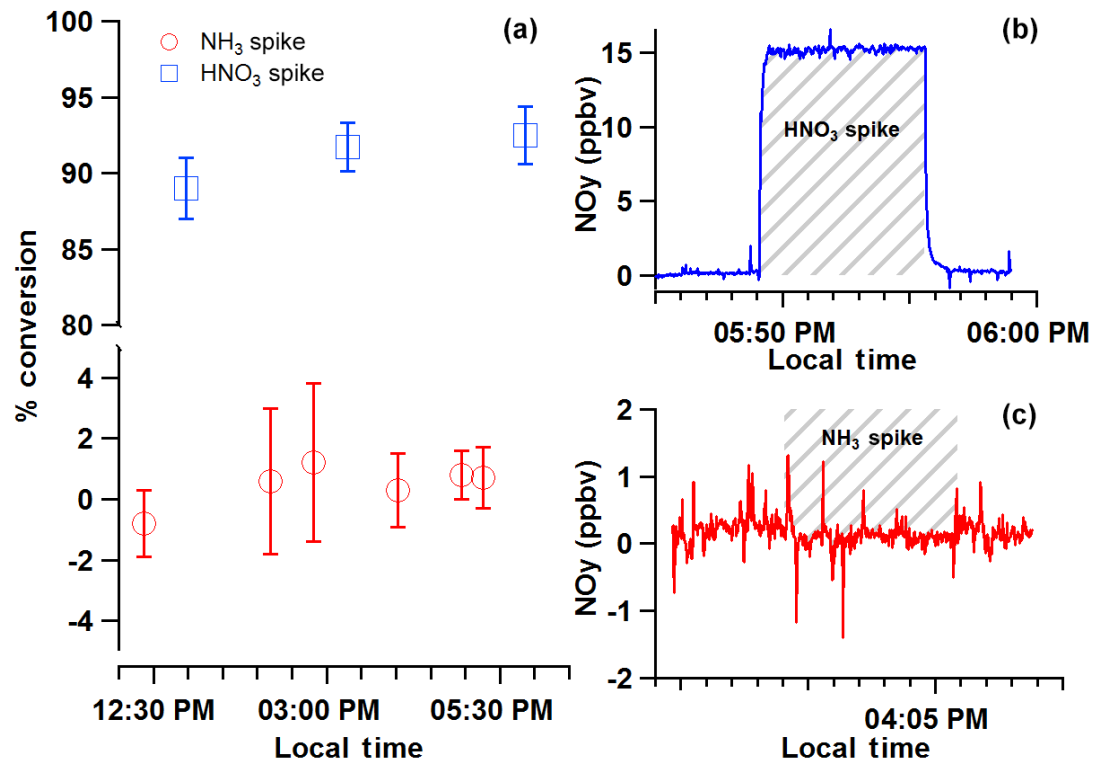

Figure 10. Measurement of $\mathrm{HNO}_{3}$ and $\mathrm{NH}_{3}$ conversion in ambient air at an inlet set temperature of $650^{\circ} \mathrm{C}$. (a) Measured conversion efficiencies for standard additions of $\mathrm{HNO}_{3}$ and $\mathrm{NH}_{3}$ to the NOAA TD-CRDS inlet sampling ambient air in Boulder, CO, on 9 August 2016. $(\mathbf{b}, \mathbf{c})$ Time series of measured $\mathrm{NO}_{y}$ during standard additions. The data are the difference between two $\mathrm{NO}_{y}$ measurement channels, one with and one without the standard addition, to cancel the variation in ambient $\mathrm{NO}_{y}$ during the tests.

as a cyclone), or a combination of the two, could be used to specifically measure aerosol nitrates, which may make up a substantial fraction of $\mathrm{NO}_{y}$, particularly in polluted wintertime urban atmospheres.

Based on the results of this paper, we make the following three recommendations. (1) TD ovens should be characterized with the appropriate reactive nitrogen compounds regularly at the oven set points using the oven residence time and gas pressure that will be used in ambient sampling. This is especially important given the findings of the Berkeley group regarding impurities found in otherwise identical ovens, as discussed in Sect. 3.1. (2) In addition to the AN and PN calibrations recommended by Day et al. (2002), Thieser et al. (2016), and others, these calibrations should include $\mathrm{HNO}_{3} . \mathrm{HNO}_{3}$ calibration will be especially important if sampling in regions where $\mathrm{HNO}_{3}$ is in large excess over other $\mathrm{NO}_{y}$ species. (3) Potential non- $\mathrm{NO}_{y}$ species such as $\mathrm{NH}_{3}$ should also be regularly introduced into the inlet under conditions where $\mathrm{O}_{3}$ is present in ambient air to check for potential conversion. These recommendations are similar to those detailed in Bradshaw et al. (1998). The results of Fig. 9 indicate that calibration results may also vary significantly when sampling in ambient air, due to the large number of possible gas-phase reactions available to the wide variety of trace atmospheric species. The last step is particularly important in instruments that detect $\mathrm{NO}$ as well as $\mathrm{NO}_{2}$. Comprehensive calibration of these interferences is key to these instruments' $\mathrm{NO}_{y}$ measurement accuracy, which in turn will provide valuable information about tropospheric $\mathrm{NO}_{x}$ chemistry.
Data availability. Data is available upon requests made to Steven Brown (steven.s.brown@noaa.gov).

\section{The Supplement related to this article is available online at doi:10.5194/amt-10-1911-2017-supplement.}

Competing interests. The authors declare that they have no conflict of interest.

Acknowledgements. We would like to thank Douglas Day for his advice on the construction and deployment of TD inlets and Jim Roberts, Tom Ryerson, Dave Parrish, and Joel Thornton for other helpful discussions. We also wish to thank Jessica Gilman for providing the GC-MS VOC mixture, Sascha Albrecht for measuring the $\mathrm{NO}_{2}$ baseline in the $\mathrm{HNO}_{3}$ permeation tube, and Jim Burkholder for the loan of a propane tank. Caroline Womack acknowledges support from the National Research Council Research Associateship Program. The authors acknowledge support from the Atmospheric Chemistry, Carbon Cycle, and Climate Program (AC4).

Edited by: D. Heard

Reviewed by: three anonymous referees 


\section{References}

Beaver, M. R., Clair, J. M. St., Paulot, F., Spencer, K. M., Crounse, J. D., LaFranchi, B. W., Min, K. E., Pusede, S. E., Wooldridge, P. J., Schade, G. W., Park, C., Cohen, R. C., and Wennberg, P. O.: Importance of biogenic precursors to the budget of organic nitrates: observations of multifunctional organic nitrates by CIMS and TD-LIF during BEARPEX 2009, Atmos. Chem. Phys., 12, 5773-5785, doi:10.5194/acp-12-5773-2012, 2012.

Bertram, T. H. and Cohen, R. C.: A prototype instrument for the real time detection of semi-volatile organic and inorganic nitrate aerosol, Eos Trans. AGU, 84, Fall Meet. Suppl., Abstract A51F0740, San Francisco, CA, USA, 8-12 December 2003.

Bertram, T. H., Thornton, J. A., and Riedel, T. P.: An experimental technique for the direct measurement of $\mathrm{N}_{2} \mathrm{O}_{5}$ reactivity on ambient particles, Atmos. Meas. Tech., 2, 231-242, doi:10.5194/amt-2-231-2009, 2009.

Bradshaw, J., Sandholm, S., and Talbot, R.: An update on reactive odd-nitrogen measurements made during recent NASA Global Tropospheric Experiment programs, J. Geophys. Res.-Atmos., 103, 19129-19148, doi:10.1029/98JD00621, 1998.

Cai, Y., Montague, D. C., Mooiweer-Bryan, W., and Deshler, T.: Performance characteristics of the ultra high sensitivity aerosol spectrometer for particles between 55 and $800 \mathrm{~nm}$ : Laboratory and field studies, J. Aerosol Sci., 39, 759-769, doi:10.1016/j.jaerosci.2008.04.007, 2008.

Crosley, D. R.: NO $y$ Blue Ribbon panel, J. Geophys. Res.-Atmos., 101, 2049-2052, doi:10.1029/95JD02276, 1996.

Darley, E. F., Kettner, K. A., and Stephens, E. R.: Analysis of peroxyacyl nitrates by gas chromatography with electron capture detection, Anal. Chem., 35, 589-591, doi:10.1021/ac60197a028, 1963.

Davidson, J. A., Viggiano, A. A., Howard, C. J., Dotan, I., Fehsenfeld, F. C., Albritton, D. L., and Ferguson, E. E.: Rate constants for the reactions of $\mathrm{O}_{2}^{+}, \mathrm{NO}_{2}^{+}, \mathrm{NO}^{+}, \mathrm{H}_{3} \mathrm{O}^{+}, \mathrm{CO}_{3}^{-}, \mathrm{NO}_{2}^{-}$, and halide ions with $\mathrm{N}_{2} \mathrm{O}_{5}$ at $300 \mathrm{~K}$, J. Chem. Phys., 68, 2085-2087, doi:10.1063/1.436032, 1978.

Day, D. A., Wooldridge, P. J., Dillon, M. B., Thornton, J. A., and Cohen, R. C.: A thermal dissociation laser-induced fluorescence instrument for in situ detection of $\mathrm{NO}_{2}$, peroxy nitrates, alkyl nitrates, and $\mathrm{HNO}_{3}$, J. Geophys. Res., 107, 4046, doi:10.1029/2001jd000779, 2002.

Day, D. A., Dillon, M. B., Wooldridge, P. J., Thornton, J. A., Rosen, R. S., Wood, E. C., and Cohen, R. C.: On alkyl nitrates, $\mathrm{O}_{3}$, and the "missing $\mathrm{NO}_{y}$ ", J. Geophys. Res., 108, 4501, doi:10.1029/2003jd003685, 2003.

DeCarlo, P. F., Slowik, J. G., Worsnop, D. R., Davidovits, P., and Jimenez, J. L.: Particle morphology and density characterization by combined mobility and aerodynamic diameter measurements. Part 1: Theory, Aerosol Sci. Tech., 38, 1185-1205, doi:10.1080/027868290903907, 2004.

Di Carlo, P., Aruffo, E., Busilacchio, M., Giammaria, F., DariSalisburgo, C., Biancofiore, F., Visconti, G., Lee, J., Moller, S., Reeves, C. E., Bauguitte, S., Forster, G., Jones, R. L., and Ouyang, B.: Aircraft based four-channel thermal dissociation laser induced fluorescence instrument for simultaneous measurements of $\mathrm{NO}_{2}$, total peroxy nitrate, total alkyl nitrate, and $\mathrm{HNO}_{3}$, Atmos. Meas. Tech., 6, 971-980, doi:10.5194/amt-6-971-2013, 2013.
Dillon, M. B., Lamanna, M. S., Schade, G. W., Goldstein, A. H., and Cohen, R. C.: Chemical evolution of the Sacramento urban plume: Transport and oxidation, J. Geophys. Res.-Atmos., 107, ACH 3-1-ACH 3-15, doi:10.1029/2001JD000969, 2002.

Dubé, W. P., Brown, S. S., Osthoff, H. D., Nunley, M. R., Ciciora, S. J., Paris, M. W., McLaughlin, R. J., and Ravishankara, A. R.: Aircraft instrument for simultaneous, in situ measurement of $\mathrm{NO}_{3}$ and $\mathrm{N}_{2} \mathrm{O}_{5}$ via pulsed cavity ring-down spectroscopy, Rev. Sci. Instrum., 77, 034101, doi:10.1063/1.2176058, 2006.

EPA: 8-Hour ozone nonattainment areas (2008 standard) in EPA Green Book, available at: http://www.epa.gov/airquality/ greenbook/map8hr_2008.html (last access: 24 March 2017), 2016.

Fahey, D. W., Eubank, C. S., Hübler, G., and Fehsenfeld, F. C.: Evaluation of a catalytic reduction technique for the measurement of total reactive odd-nitrogen $\mathrm{NO}_{y}$ in the atmosphere, J. Atmos. Chem., 3, 435-468, doi:10.1007/bf00053871, 1985.

Fahey, D. W., Hübler, G., Parrish, D. D., Williams, E. J., Norton, R. B., Ridley, B. A., Singh, H. B., Liu, S. C., and Fehsenfeld, F. C.: Reactive nitrogen species in the troposphere: Measurements of $\mathrm{NO}, \mathrm{NO}_{2}, \mathrm{HNO}_{3}$, particulate nitrate, peroxyacetyl nitrate (PAN), $\mathrm{O}_{3}$, and total reactive odd nitrogen $\left(\mathrm{NO}_{y}\right)$ at Niwot Ridge, Colorado, J. Geophys. Res., 91, 9781-9793, 1986.

Fehsenfeld, F. C., Huey, L. G., Sueper, D. T., Norton, R. B., Williams, E. J., Eisele, F. L., Mauldin, R. L., and Tanner, D. J.: Ground-based intercomparison of nitric acid measurement techniques, J. Geophys. Res.-Atmos., 103, 3343-3353, doi:10.1029/97JD02213, 1998.

Flocke, F. M., Weinheimer, A. J., Swanson, A. L., Roberts, J. M., Schmitt, R., and Shertz, S.: On the measurement of PANs by gas chromatography and electron capture detection, J. Atmos. Chem., 52, 19-43, doi:10.1007/s10874-005-6772-0, 2005.

Fuchs, H., Dubé, W. P., Lerner, B. M., Wagner, N. L., Williams, E. J., and Brown, S. S.: A sensitive and versatile detector for atmospheric $\mathrm{NO}_{2}$ and $\mathrm{NO}_{x}$ based on blue diode laser cavity ring-down spectroscopy, Environ. Sci. Technol., 43, 7831-7836, doi:10.1021/es902067h, 2009.

Glänzer, K. and Troe, J.: Thermal decomposition of nitrocompounds in shock waves. IV: Decomposition of nitric acid, Berich. Bunsen. Gesell., 78, 71-76, doi:10.1002/bbpc.19740780112, 1974.

Huey, L. G.: Measurement of trace atmospheric species by chemical ionization mass spectrometry: Speciation of reactive nitrogen and future directions, Mass Spectrom. Rev., 26, 166-184, doi:10.1002/mas.20118, 2007.

Huey, L. G., Dunlea, E. J., Lovejoy, E. R., Hanson, D. R., Norton, R. B., Fehsenfeld, F. C., and Howard, C. J.: Fast time response measurements of $\mathrm{HNO}_{3}$ in air with a chemical ionization mass spectrometer, J. Geophys. Res.-Atmos., 103, 3355-3360, doi:10.1029/97JD02214, 1998.

Johnston, H. S., Cantrell, C. A., and Calvert, J. G.: Unimolecular decomposition of $\mathrm{NO}_{3}$ to form $\mathrm{NO}$ and $\mathrm{O}_{2}$ and a review of $\mathrm{N}_{2} \mathrm{O}_{5} / \mathrm{NO}_{3}$ kinetics, J. Geophys. Res.-Atmos., 91, 5159-5172, doi:10.1029/JD091iD04p05159, 1986.

Kercher, J. P., Riedel, T. P., and Thornton, J. A.: Chlorine activation by $\mathrm{N}_{2} \mathrm{O}_{5}$ : simultaneous, in situ detection of $\mathrm{ClNO}_{2}$ and $\mathrm{N}_{2} \mathrm{O}_{5}$ by chemical ionization mass spectrometry, Atmos. Meas. Tech., 2, 193-204, doi:10.5194/amt-2-193-2009, 2009. 
King, M. D., Dick, E. M., and Simpson, W. R.: A new method for the atmospheric detection of the nitrate radical $\left(\mathrm{NO}_{3}\right)$, Atmos. Environ., 34, 685-688, doi:10.1016/S1352-2310(99)00418-5, 2000.

Kley, D. and McFarland, M.: Chemiluminescence detector for NO and $\mathrm{NO}_{2}$, Atmospheric Technology, 12, 63-69, 1980.

Kliner, D. A. V., Daube, B. C., Burley, J. D., and Wofsy, S. C.: Laboratory investigation of the catalytic reduction technique for measurement of atmospheric $\mathrm{NO}_{y}$, J. Geophys. Res.-Atmos., 102, 10759-10776, doi:10.1029/96JD03816, 1997.

Lee, B. H., Lopez-Hilfiker, F. D., Mohr, C., Kurtén, T., Worsnop, D. R., and Thornton, J. A.: An iodide-adduct high-resolution time-of-flight chemical-ionization mass spectrometer: Application to atmospheric inorganic and organic compounds, Environ. Sci. Technol., 48, 6309-6317, doi:10.1021/es500362a, 2014.

Lee, B. H., Mohr, C., Lopez-Hilfiker, F. D., Lutz, A., Hallquist, M., Lee, L., Romer, P., Cohen, R. C., Iyer, S., Kurtén, T., Hu, W., Day, D. A., Campuzano-Jost, P., Jimenez, J. L., Xu, L., Ng, N. L., Guo, H., Weber, R. J., Wild, R. J., Brown, S. S., Koss, A., de Gouw, J., Olson, K., Goldstein, A. H., Seco, R., Kim, S., McAvey, K., Shepson, P. B., Starn, T., Baumann, K., Edgerton, E. S., Liu, J., Shilling, J. E., Miller, D. O., Brune, W., Schobesberger, S., D'Ambro, E. L., and Thornton, J. A.: Highly functionalized organic nitrates in the southeast United States: Contribution to secondary organic aerosol and reactive nitrogen budgets, P. Natl. Acad. Sci. USA, 113, 1516-1521, doi:10.1073/pnas.1508108113, 2016.

Manion, J. A., Huie, R. E., Levin, R. D., Burgess Jr., D. R., Orkin, V. L., Tsang, W., McGivern, W. S., Hudgens, J. W., Knyazev, V. D., Atkinson, D. B., Chai, E., Tereza, A. M., Lin, C.-Y., Allison, T. C., Mallard, W. G., Westley, F., Herron, J. T., Hampson, R. F., and Frizzell, D. H.: NIST Chemical Kinetics Database, NIST Standard Reference Database 17, Version 7.0 (Web Version), Release 1.6.8, Data version 2015.12, available at: http://kinetics.nist.gov (last access: 24 March 2017), 2015.

Neuman, J. A., Huey, L. G., Ryerson, T. B., and Fahey, D. W.: Study of inlet materials for sampling atmospheric nitric acid, Environ. Sci. Technol., 33, 1133-1136, doi:10.1021/es980767f, 1999.

Neuman, J. A., Huey, L. G., Dissly, R. W., Fehsenfeld, F. C., Flocke, F., Holecek, J. C., Holloway, J. S., Hübler, G., Jakoubek, R., Nicks, D. K., Parrish, D. D., Ryerson, T. B., Sueper, D. T., and Weinheimer, A. J.: Fast-response airborne in situ measurements of $\mathrm{HNO}_{3}$ during the Texas 2000 Air Quality Study, J. Geophys. Res.-Atmos., 107, 4436, doi:10.1029/2001JD001437, 2002.

Neuman, J. A., Ryerson, T. B., Huey, L. G., Jakoubek, R., Nowak, J. B., Simons, C., and Fehsenfeld, F. C.: Calibration and evaluation of nitric acid and ammonia permeation tubes by UV optical absorption, Environ. Sci. Technol., 37, 2975, doi:10.1021/es0264221, 2003.

Neuman, J. A., Aikin, K. C., Atlas, E. L., Blake, D. R., Holloway, J. S., Meinardi, S., Nowak, J. B., Parrish, D. D., Peischl, J., Perring, A. E., Pollack, I. B., Roberts, J. M., Ryerson, T. B., and Trainer, M.: Ozone and alkyl nitrate formation from the Deepwater Horizon oil spill atmospheric emissions, J. Geophys. Res.-Atmos., 117, D09305, doi:10.1029/2011JD017150, 2012.

Nikitas, C., Clemitshaw, K. C., Oram, D. E., and Penkett, S. A.: Measurement of PAN in the polluted boundary layer and free troposphere using a luminol- $\mathrm{NO}_{2}$ detector combined with a thermal converter, J. Atmos. Chem., 28, 339-359, doi:10.1023/A:1005898017520, 1997.

O’Brien, J. M., Shepson, P. B., Muthuramu, K., Hao, C., Niki, H., Hastie, D. R., Taylor, R., and Roussel, P. B.: Measurements of alkyl and multifunctional organic nitrates at a rural site in Ontario, J. Geophys. Res.-Atmos., 100, 22795-22804, doi:10.1029/94JD03247, 1995.

O'Keefe, A. and Deacon, D. A. G.: Cavity ring-down optical spectrometer for absorption measurements using pulsed laser sources, Rev. Sci. Instrum., 59, 2544-2551, doi:10.1063/1.1139895, 1988.

Paul, D., Furgeson, A., and Osthoff, H. D.: Measurements of total peroxy and alkyl nitrate abundances in laboratory-generated gas samples by thermal dissociation cavity ring-down spectroscopy, Rev. Sci. Instrum., 80, 114101, doi:10.1063/1.3258204, 2009.

Pérez, I. M., Wooldridge, P. J., and Cohen, R. C.: Laboratory evaluation of a novel thermal dissociation chemiluminescence method for in situ detection of nitrous acid, Atmos. Environ., 41, 3993 4001, doi:10.1016/j.atmosenv.2007.01.060, 2007.

Perner, D. and Platt, U.: Detection of nitrous acid in the atmosphere by differential optical absorption, Geophys. Res. Lett., 6, $917-$ 920, doi:10.1029/GL006i012p00917, 1979.

Phillips, G. J., Pouvesle, N., Thieser, J., Schuster, G., Axinte, R., Fischer, H., Williams, J., Lelieveld, J., and Crowley, J. N.: Peroxyacetyl nitrate (PAN) and peroxyacetic acid (PAA) measurements by iodide chemical ionisation mass spectrometry: first analysis of results in the boreal forest and implications for the measurement of PAN fluxes, Atmos. Chem. Phys., 13, 11291139, doi:10.5194/acp-13-1129-2013, 2013.

Pusede, S. E., Duffey, K. C., Shusterman, A. A., Saleh, A., Laughner, J. L., Wooldridge, P. J., Zhang, Q., Parworth, C. L., Kim, H., Capps, S. L., Valin, L. C., Cappa, C. D., Fried, A., Walega, J., Nowak, J. B., Weinheimer, A. J., Hoff, R. M., Berkoff, T. A., Beyersdorf, A. J., Olson, J., Crawford, J. H., and Cohen, R. C.: On the effectiveness of nitrogen oxide reductions as a control over ammonium nitrate aerosol, Atmos. Chem. Phys., 16, 2575 2596, doi:10.5194/acp-16-2575-2016, 2016.

Ridley, B. A. and Howlett, L. C.: An instrument for nitric oxide measurements in the stratosphere, Rev. Sci. Instrum., 45, 742746, doi:10.1063/1.1686726, 1974.

Rollins, A. W., Smith, J. D., Wilson, K. R., and Cohen, R. C.: Real time in situ detection of organic nitrates in atmospheric aerosols, Environ. Sci. Technol., 44, 5540-5545, doi:10.1021/es100926x, 2010.

Sadanaga, Y., Takaji, R., Ishiyama, A., Nakajima, K., Matsuki, A., and Bandow, H.: Thermal dissociation cavity attenuated phase shift spectroscopy for continuous measurement of total peroxy and organic nitrates in the clean atmosphere, Rev. Sci. Instrum., 87, 074102, doi:10.1063/1.4958167, 2016.

Sander, S. P., Abbatt, J., Barker, J. R., Burkholder, J. B., Friedl, R. R., Golden, D. M., Huie, R. E., Kolb, C. E., Kurylo, M. J., Moortgat, G. K., Orkin, V. L., and Wine, P. H.: Chemical kinetics and photochemical data for use in atmospheric studies. Evaluation No. 17, available at: http://jpldataeval.jpl.nasa.gov/ (last access: 24 March 2017), 2011.

Schott, G. and Davidson, N.: Shock waves in chemical kinetics: The decomposition of $\mathrm{N}_{2} \mathrm{O}_{5}$ at high temperatures, J. Am. Chem. Soc., 80, 1841-1853, doi:10.1021/ja01541a019, 1958. 
Slusher, D. L., Huey, L. G., Tanner, D. J., Flocke, F. M., and Roberts, J. M.: A thermal dissociation-chemical ionization mass spectrometry (TD-CIMS) technique for the simultaneous measurement of peroxyacyl nitrates and dinitrogen pentoxide, J. Geophys. Res.-Atmos., 109, D19315, doi:10.1029/2004JD004670, 2004.

Smith, J. N., Moore, K. F., McMurry, P. H., and Eisele, F. L.: Atmospheric measurements of sub- $20 \mathrm{~nm}$ diameter particle chemical composition by thermal desorption chemical ionization mass spectrometry, Aerosol Sci. Tech., 38, 100-110, doi:10.1080/02786820490249036, 2004.

Sobanski, N., Schuladen, J., Schuster, G., Lelieveld, J., and Crowley, J. N.: A five-channel cavity ring-down spectrometer for the detection of $\mathrm{NO}_{2}, \mathrm{NO}_{3}, \mathrm{~N}_{2} \mathrm{O}_{5}$, total peroxy nitrates and total alkyl nitrates, Atmos. Meas. Tech., 9, 5103-5118, doi:10.5194/amt-9-5103-2016, 2016.

Talbot, R. W., Vijgen, A. S., and Harriss, R. C.: Measuring tropospheric $\mathrm{HNO}_{3}$ : Problems and prospects for nylon filter and mist chamber techniques, J. Geophys. Res.-Atmos., 95, 7553-7561, doi:10.1029/JD095iD06p07553, 1990.

Thaler, R. D., Mielke, L. H., and Osthoff, H. D.: Quantification of nitryl chloride at part per trillion mixing ratios by thermal dissociation cavity ring-down spectroscopy, Anal. Chem., 83, 27612766, doi:10.1021/ac200055z, 2011.

Thieser, J., Schuster, G., Schuladen, J., Phillips, G. J., Reiffs, A., Parchatka, U., Pöhler, D., Lelieveld, J., and Crowley, J. N.: A two-channel thermal dissociation cavity ring-down spectrometer for the detection of ambient $\mathrm{NO}_{2}, \mathrm{RO}_{2} \mathrm{NO}_{2}$ and $\mathrm{RONO}_{2}$, Atmos. Meas. Tech., 9, 553-576, doi:10.5194/amt-9-553-2016, 2016.

Thornton, J. A., Wooldridge, P. J., and Cohen, R. C.: Atmospheric $\mathrm{NO}_{2}$ : In situ laser-induced fluorescence detection at parts per trillion mixing ratios, Anal. Chem., 72, 528-539, doi:10.1021/ac9908905, 2000.

Veres, P. R., Roberts, J. M., Wild, R. J., Edwards, P. M., Brown, S. S., Bates, T. S., Quinn, P. K., Johnson, J. E., Zamora, R. J., and de Gouw, J.: Peroxynitric acid $\left(\mathrm{HO}_{2} \mathrm{NO}_{2}\right)$ measurements during the UBWOS 2013 and 2014 studies using iodide ion chemical ionization mass spectrometry, Atmos. Chem. Phys., 15, 81018114, doi:10.5194/acp-15-8101-2015, 2015.

Voisin, D., Smith, J. N., Sakurai, H., McMurry, P. H., and Eisele, F. L.: Thermal desorption chemical ionization mass spectrometer for ultrafine particle chemical composition, Aerosol Sci. Tech., 37, 471-475, doi:10.1080/02786820300959, 2003.

Wagner, N. L., Dubé, W. P., Washenfelder, R. A., Young, C. J., Pollack, I. B., Ryerson, T. B., and Brown, S. S.: Diode laser-based cavity ring-down instrument for $\mathrm{NO}_{3}, \mathrm{~N}_{2} \mathrm{O}_{5}, \mathrm{NO}$, $\mathrm{NO}_{2}$ and $\mathrm{O}_{3}$ from aircraft, Atmos. Meas. Tech., 4, 1227-1240, doi:10.5194/amt-4-1227-2011, 2011.

Washenfelder, R. A., Wagner, N. L., Dubé, W. P., and Brown, S. S.: Measurement of atmospheric ozone by cavity ringdown spectroscopy, Environ. Sci. Technol., 45, 2938-2944, doi:10.1021/es103340u, 2011.
Wild, R. J., Edwards, P. M., Dubé, W. P., Baumann, K., Edgerton, E. S., Quinn, P. K., Roberts, J. M., Rollins, A. W., Veres, P. R., Warneke, C., Williams, E. J., Yuan, B., and Brown, S. S.: A measurement of total reactive nitrogen, $\mathrm{NO}_{y}$, together with $\mathrm{NO}_{2}, \mathrm{NO}$, and $\mathrm{O}_{3}$ via cavity ring-down spectroscopy, Environ. Sci. Technol., 48, 9609-9615, doi:10.1021/es501896w, 2014.

Wild, R. J., Edwards, P. M., Bates, T. S., Cohen, R. C., de Gouw, J. A., Dubé, W. P., Gilman, J. B., Holloway, J., Kercher, J., Koss, A. R., Lee, L., Lerner, B. M., McLaren, R., Quinn, P. K., Roberts, J. M., Stutz, J., Thornton, J. A., Veres, P. R., Warneke, C., Williams, E., Young, C. J., Yuan, B., Zarzana, K. J., and Brown, S. S.: Reactive nitrogen partitioning and its relationship to winter ozone events in Utah, Atmos. Chem. Phys., 16, 573583, doi:10.5194/acp-16-573-2016, 2016.

Williams, E. J., Baumann, K., Roberts, J. M., Bertman, S. B., Norton, R. B., Fehsenfeld, F. C., Springston, S. R., Nunnermacker, L. J., Newman, L., Olszyna, K., Meagher, J., Hartsell, B., Edgerton, E., Pearson, J. R., and Rodgers, M. O.: Intercomparison of ground-based $\mathrm{NO}_{y}$ measurement techniques, J. Geophys. Res.Atmos., 103, 22261-22280, doi:10.1029/98JD00074, 1998.

Winer, A. M., Peters, J. W., Smith, J. P., and Pitts, J. N.: Response of commercial chemiluminescent nitric oxide-nitrogen dioxide analyzers to other nitrogen-containing compounds, Environ. Sci. Technol., 8, 1118-1121, doi:10.1021/es60098a004, 1974.

Wooldridge, P. J., Perring, A. E., Bertram, T. H., Flocke, F. M., Roberts, J. M., Singh, H. B., Huey, L. G., Thornton, J. A., Wolfe, G. M., Murphy, J. G., Fry, J. L., Rollins, A. W., LaFranchi, B. W., and Cohen, R. C.: Total Peroxy Nitrates ( $\mathrm{PPNs}$ ) in the atmosphere: the Thermal Dissociation-Laser Induced Fluorescence (TD-LIF) technique and comparisons to speciated PAN measurements, Atmos. Meas. Tech., 3, 593-607, doi:10.5194/amt-3-5932010, 2010.

Worton, D. R., Mills, G. P., Oram, D. E., and Sturges, W. T.: Gas chromatography negative ion chemical ionization mass spectrometry: Application to the detection of alkyl nitrates and halocarbons in the atmosphere, J. Chromatogr. A, 1201, 112-119, doi:10.1016/j.chroma.2008.06.019, 2008.

Xiong, F., McAvey, K. M., Pratt, K. A., Groff, C. J., Hostetler, M. A., Lipton, M. A., Starn, T. K., Seeley, J. V., Bertman, S. B., Teng, A. P., Crounse, J. D., Nguyen, T. B., Wennberg, P. O., Misztal, P. K., Goldstein, A. H., Guenther, A. B., Koss, A. R., Olson, K. F., de Gouw, J. A., Baumann, K., Edgerton, E. S., Feiner, P. A., Zhang, L., Miller, D. O., Brune, W. H., and Shepson, P. B.: Observation of isoprene hydroxynitrates in the southeastern United States and implications for the fate of $\mathrm{NO}_{x}$, Atmos. Chem. Phys., 15, 11257-11272, doi:10.5194/acp-15-11257-2015, 2015.

Zheng, W., Flocke, F. M., Tyndall, G. S., Swanson, A., Orlando, J. J., Roberts, J. M., Huey, L. G., and Tanner, D. J.: Characterization of a thermal decomposition chemical ionization mass spectrometer for the measurement of peroxy acyl nitrates (PANs) in the atmosphere, Atmos. Chem. Phys., 11, 6529-6547, doi:10.5194/acp-11-6529-2011, 2011. 